Article

\title{
Synthesis and Biological Evaluation of
} 1,3-Dideazapurine-Like 7-Amino-5-HydroxymethylBenzimidazole Ribonucleoside Analogues as Aminoacyl-tRNA Synthetase Inhibitors

\author{
Baole Zhang ${ }^{1,+} \neq$, Luping Pang ${ }^{1,2,+}$, Manesh Nautiyal ${ }^{1}\left(\mathbb{D}\right.$, Steff De Graef ${ }^{2, \S} \mathbb{D}^{\mathrm{D}}$, Bharat Gadakh ${ }^{1}$, \\ Eveline Lescrinier ${ }^{1} \mathbb{D}$, Jef Rozenski ${ }^{1}$, Sergei V. Strelkov ${ }^{2} \mathbb{D}$, Stephen D. Weeks ${ }^{2, \S} \mathbb{D}$ and \\ Arthur Van Aerschot 1,*(D) \\ 1 Rega Institute for Medical Research, Medicinal Chemistry, KU Leuven, Herestraat 49-box 1041, \\ 3000 Leuven, Belgium; zhangbaole.2008@163.com (B.Z.); Luping.Pang@kuleuven.be (L.P.); \\ manesh2006@gmail.com (M.N.); bkgadakh@gmail.com (B.G.); Eveline.Lescrinier@kuleuven.be (E.L.); \\ Jef.Rozenski@kuleuven.be (J.R.) \\ 2 Laboratory for Biocrystallography, Department of Pharmaceutical and Pharmacological Sciences, \\ KU Leuven, Herestraat 49-box 822, 3000 Leuven, Belgium; Steff.Degraef@kuleuven.be (S.D.G.); \\ Sergei.Strelkov@kuleuven.be (S.V.S.); sweeks@orthogontherapeutics.com (S.D.W.) \\ * Correspondence: Arthur.Vanaerschot@kuleuven.be \\ + These authors contributed equally to this work. \\ $\ddagger$ Present address: Hybio Medicine Park, No.37 Keji C, Str. 2nd, Shenzhen Hi-Tech Industrial Park, \\ Shenzhen 518000, China. \\ $\S$ Present address: OrthogonX, Gaston Geenslaan 1, 3001 Leuven, Belgium.
}

Academic Editor: Katherine Seley-Radtke

Received: 24 September 2020; Accepted: 15 October 2020; Published: 16 October 2020

\begin{abstract}
Aminoacyl-tRNA synthetases (aaRSs) have become viable targets for the development of antimicrobial agents due to their crucial role in protein translation. A series of six amino acids were coupled to the purine-like 7-amino-5-hydroxymethylbenzimidazole nucleoside analogue following an optimized synthetic pathway. These compounds were designed as aaRS inhibitors and can be considered as 1,3-dideazaadenine analogues carrying a 2-hydroxymethyl substituent. Despite our intentions to obtain $N^{1}$-glycosylated 4-aminobenzimidazole congeners, resembling the natural purine nucleosides glycosylated at the $N^{9}$-position, we obtained the $N^{3}$-glycosylated benzimidazole derivatives as the major products, resembling the respective purine $N^{7}$-glycosylated nucleosides. A series of X-ray crystal structures of class I and II aaRSs in complex with newly synthesized compounds revealed interesting interactions of these "base-flipped" analogues with their targets. While the exocyclic amine of the flipped base mimics the reciprocal interaction of the $N^{3}$-purine atom of aminoacyl-sulfamoyl adenosine (aaSA) congeners, the hydroxymethyl substituent of the flipped base apparently loses part of the standard interactions of the adenine $N^{1}$ and the $N^{6}$-amine as seen with aaSA analogues. Upon the evaluation of the inhibitory potency of the newly obtained analogues, nanomolar inhibitory activities were noted for the leucine and isoleucine analogues targeting class I aaRS enzymes, while rather weak inhibitory activity against the corresponding class II aaRSs was observed. This class bias could be further explained by detailed structural analysis.
\end{abstract}

Keywords: aminoacyl sulfamoylated nucleosides; aaRS inhibition; structure-activity relationship; sugar-base condensation; heterocycle glycosylation 


\section{Introduction}

The aminoacyl-tRNA synthetases (aaRSs) are essential enzymes playing a central role in the translation of the genetic code and hence constitute a viable target for the development of antibiotics [1]. Based on the structure of the catalytic site, two distinct classes of tRNA synthetases can be discerned [2,3]. Both classes activate an amino acid in forming the respective aminoacyl-adenylate (aa-AMP, Figure 1a) as natural reaction intermediates. In view of their resemblance and irrespective of the class, aminoacyl-sulfamoyl adenosine (aaSA, Figure 1b) derivatives are well-known high-affinity aaRS inhibitors, but they lack antibacterial activity due to their low uptake potential [4]. By introducing various linkers or base substitutions on the aaSA scaffold, our group has already made large biochemical and structural efforts for the evaluation of various series of modified aaSA analogues. More recently, this resulted in the synthesis of 3-deazaadenosine derivatives (aaS3DA, Figure 1c) [3]. These proved less prone to cyclonucleoside formation via the attack of the $\mathrm{N}^{3}$-position on $\mathrm{C}^{\prime}{ }^{\prime}$ with the concomitant release of the sulfamate moiety [5].

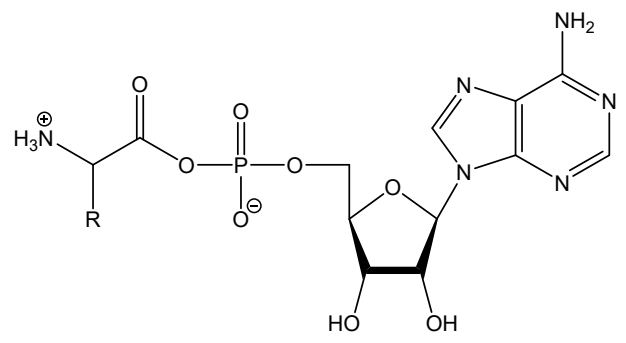

a. aminoacyl- AMP

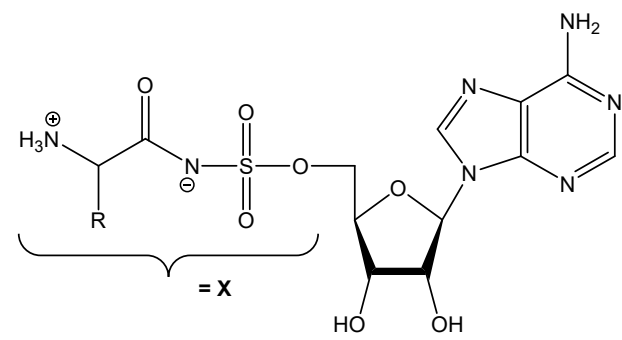

b. aaSA

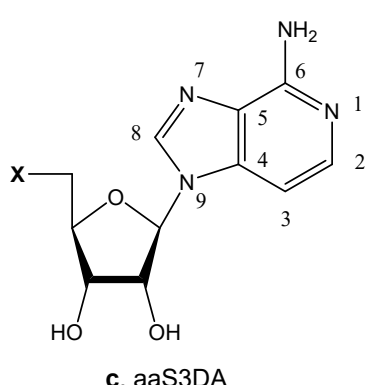

c. aaS3DA

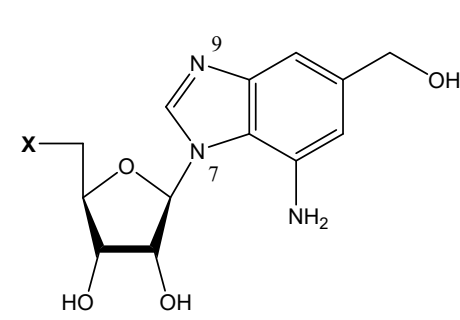

d. $N^{7}$-aaSHMDDA

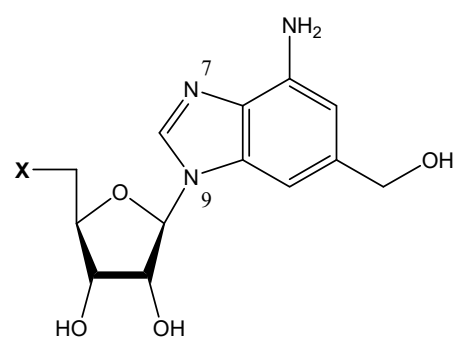

e. $N^{9}$-aaSHMDDA

Figure 1. Chemical structures for (a) aminoacyl-adenylate; (b) aminoacyl-sulfamoyl adenosines; (c) aminoacyl-sulfamoyl 3-deazaadenosines; (d) the obtained $N^{7}$-glycosylated 1,3-dideaza-2-hydroxymethyl-adenosine (aaS7HMDDA), and (e) the desired $N^{9}$-glycosylated analogues of 1,3-dideaza2-hydroxymethyladenine (aaS9HMDDA). Atom numbering according to nucleoside nomenclature.

In addition, our group in the past already evaluated several alternative bases, among which was 4-amino-benzimidazole as a possible substitution for adenine [6]. The former proved less potent, resulting from the loss of $N^{3}$-hydrogen bonding as seen with adenine. Moreover, upon evaluation of the above-mentioned 3-deazaadenosine analogues, we observed a clear class bias for aaRS enzymes belonging preferentially to class I versus class II. Careful analysis of the available crystallographic structures pointed to the presence of a conserved water molecule promoting base recognition within class II enzymes via H-bonding with $N^{3}$ [3]. Therefore, various substituents have been examined by molecular docking, which potentially could restore the enzymatic affinity.

J. Lee et al. [7] reported a small cavity around the C2-position of adenine from their docking study of IleSA's interaction with the IleRS enzyme. Preliminary modeling indicated to us that the introduction of a 2-hydroxymethyl group on the 1,3-dideaza-adenine base could afford improved interaction and affinity for the enzyme. The thus-proposed scaffold can be considered as either 4-amino-6-hydroxymethyl-benzimidazole or a 1,3-dideaza-2-hydroxymethyl-adenine ring structure. Moreover, purine ribonucleosides carrying a 2-hydroxymethyl moiety have been prepared in the past 
by hetero-cyclizations [8,9] or transformations of 2-vinylpurines [10,11]. 2-(hydroxymethyl)-nebularine was reported to exhibit antiviral activity [12], 2-(hydroxymethyl)inosine monophosphate to inhibit IMP dehydrogenase [8], and protected 2-(hydroxymethyl)inosine was used in the construction of inhibitors of GMP synthetase [9]. Interestingly, a recent report of the group of Roper discussed the beneficial effects of, in particular, C2-arylated adenosine congeners as inhibitors of bacterial seryl-tRNA synthetase, attaining selective inhibition with greater than two orders of magnitude compared to that for their human homologue [13].

The proposed deviation of the adenine structure should not deter us, as already in the past, compounds carrying highly modified base moieties have been reported to be highly efficient aaRS inhibitory compounds, as briefly exemplified by the high selectivity of aryl-tetrazole analogues as inhibitors of IleRS [14], and the excellent efficacy of the warhead metabolite of albomycin as a SerRS inhibitor [15]. Both findings proved that altering the adenine base structure while preserving the aaRS inhibitory activity is feasible within both aaRS classes. All this led us to investigate 1,3-dideaza-2-hydroxymethyl-adenosine (HMDDA) as a nucleoside scaffold to further study the structure-activity relationships of these non-hydrolysable aa-AMP mimics for aaRS inhibition.

However, a series of flipped base derivatives were obtained (resembling an $N^{7}$-glycosylated purine, Figure 1d) despite our efforts to generate the resembling $N^{9}$-glycosylated purine analogues (Figure 1e). X-ray analysis further confirmed the structures for the flipped-base analogues and showed interesting interactions with the respective aaRS, with a water molecule now H-bonding with the flipped exocyclic amine moiety and substituting for the adenine $N^{3}$-water interaction as seen with regular nucleosides interacting with class II enzymes. This series of $5^{\prime}$-aminoacylated sulfamoyl-7-amino-5-hydroxymethyl-benzimidazol-1-yl ribosides (changed numbering as of glycosylation of the alternative nitrogen atom) can be considered as well as close nucleoside analogues being aminoacylated, $N^{7}$-glycosylated 2-hydroxymethyl-1,3-dideazaadenine (aaS7HMDDA, Figure 1d) congeners, in contrast with the expected $N^{9}$-glycosylated 2-hydroxymethyl-1,3-dideazaadenine (aaS9HMDDA, Figure 1e) analogues. In this study, we describe the synthesis of these new aaRS inhibitors, and the evaluation of their inhibitory potency, and provide details on their 3D enzyme interactions as obtained via X-ray crystallography.

\section{Results}

\subsection{Synthesis of aaSHMDDA Analogues}

The initially planned scheme to achieve the synthesis of 6 from cheap and readily available 4-chlorobenzoic acid $\mathbf{1}$ is shown in Scheme 1. Compound $\mathbf{2}$ was obtained by the nitration of $\mathbf{1}$, followed by treatment with ammonia and substituting an amine for the chlorine atom to afford 3 [16]. The selective reduction of one nitro group using the method described by V. Milata et al. [17] led to the synthesis of 4 with a high yield, using only water as the solvent and inexpensive reagents. The cyclization step to obtain $\mathbf{5}$ was performed under reflux conditions in formic acid [16]. The yield proved relatively low, most likely because of the presence of the carboxylic acid moiety. An attempt to obtain 6 by reducing the carboxylic acid of compound 5 following the method introduced by Y. Ida et al. [18] was not successful. The esterification of 5 was carried out in methanol in the presence of $\mathrm{SOCl}_{2}$ to afford 7 [16]. The same reduction procedure as used for $\mathbf{5}$ was applied to 7 , but we were still unable to obtain the target compound $\mathbf{6}$, and only trace amounts were detected upon mass spectrometric analysis. The failure of the reduction step and the low yields can be ascribed most probably to the acidic moiety, causing mainly problems for work-up and purification.

In view of the perceived difficulties in obtaining 6, we turned to another route where the carboxylic group was reduced at an earlier stage. The synthesis of 8 was achieved by applying the previous reduction protocol on $\mathbf{2}$ with a very good yield. Compounds 9, 10 and $\mathbf{1 1}$ were synthesized in analogy with the synthesis of $\mathbf{3}$ to $\mathbf{5}$, respectively, but with improved yields. Unexpectedly, $\mathbf{1 1}$ was obtained as the formate, which can be easily hydrolyzed to the desired compound $\mathbf{6}$ (Scheme 1). 

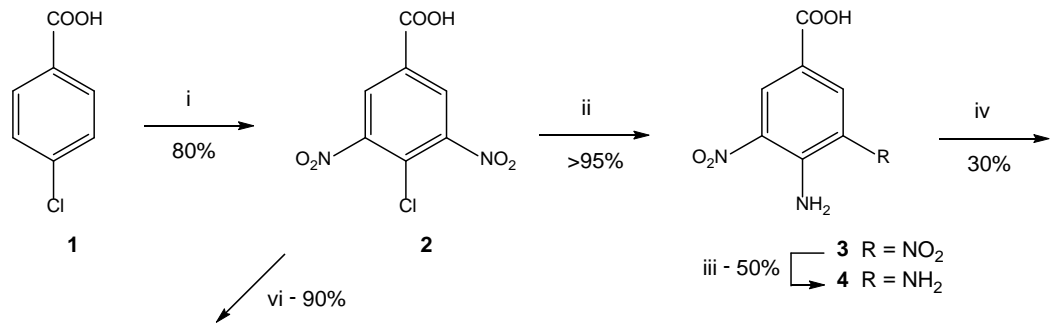<smiles>O=C(O)c1cc([N+](=O)[O-])c2nc[nH]c2c1</smiles>

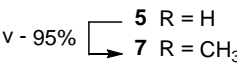<smiles>CCCCCCCO</smiles>

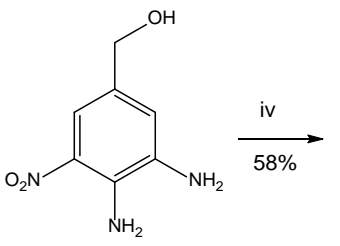<smiles>O=COCc1cc([N+](=O)[O-])c2nc[nH]c2c1</smiles><smiles>C[13CH3]</smiles><smiles>O=[N+]([O-])c1cc(CO)cc2[nH]cnc12</smiles>

\begin{aligned} ii $-92 \% \square & 8 \mathrm{R}=\mathrm{Cl} \\$\hline & $\mathbf{R}=\mathrm{NH}_{2}\end{aligned}$

10

Scheme 1. Synthesis of 6-hydroxymethyl-4-nitro-benzimidazole. Reagents and conditions: (i) conc. $\mathrm{H}_{2} \mathrm{SO}_{4}, \mathrm{KNO}_{3}, 130^{\circ} \mathrm{C}$; (ii) methanol, aqueous ammonia, $65^{\circ} \mathrm{C}$; (iii) methanol/water (3:1), sodium sulfide, sodium hydrogen carbonate, $75^{\circ} \mathrm{C}$; (iv) formic acid, $115{ }^{\circ} \mathrm{C}$; (v) methanol, $\mathrm{SOCl}_{2}$, conc. $\mathrm{H}_{2} \mathrm{SO}_{4}$, reflux; (vi) tetrahydrofuran (THF), boron trifluoride diethyl etherate, borane-THF complex, $50{ }^{\circ} \mathrm{C}$; (vii) $7 \mathrm{~N}$ ammonia in methanol.

The glycosylation of unprotected 6 with 1,2,3,5-tetra-O-acetyl- $\beta$-D-ribofuranose (Scheme 2) was carried out according to published procedures using stannic chloride [19]. Although the major product was thought to be the desired compound based on mass spectroscopic analysis, extensive 2D NMR analysis confirmed the product to be compound $\mathbf{1 2}$ (correlation signals were found for $\mathrm{H}^{1^{\prime}}$ with $\mathrm{C}^{2^{\prime \prime}}$ and $\mathrm{C}^{1^{\prime}}$ with $\mathrm{H}^{2^{\prime \prime}}$, following the atom numbering as found in Scheme 3). Likewise, when using tert-butyldimethylsilyl (TBDMS)-protected 13 or tert-butyldiphenylsilyl (TBDPS)-protected 14 under the same conditions, compound $\mathbf{1 2}$ remained the major product. Increasing the reaction time afforded the double glycosylated product 15 with a low yield (ratio 3:1 for 12 versus 15) as confirmed by NMR.

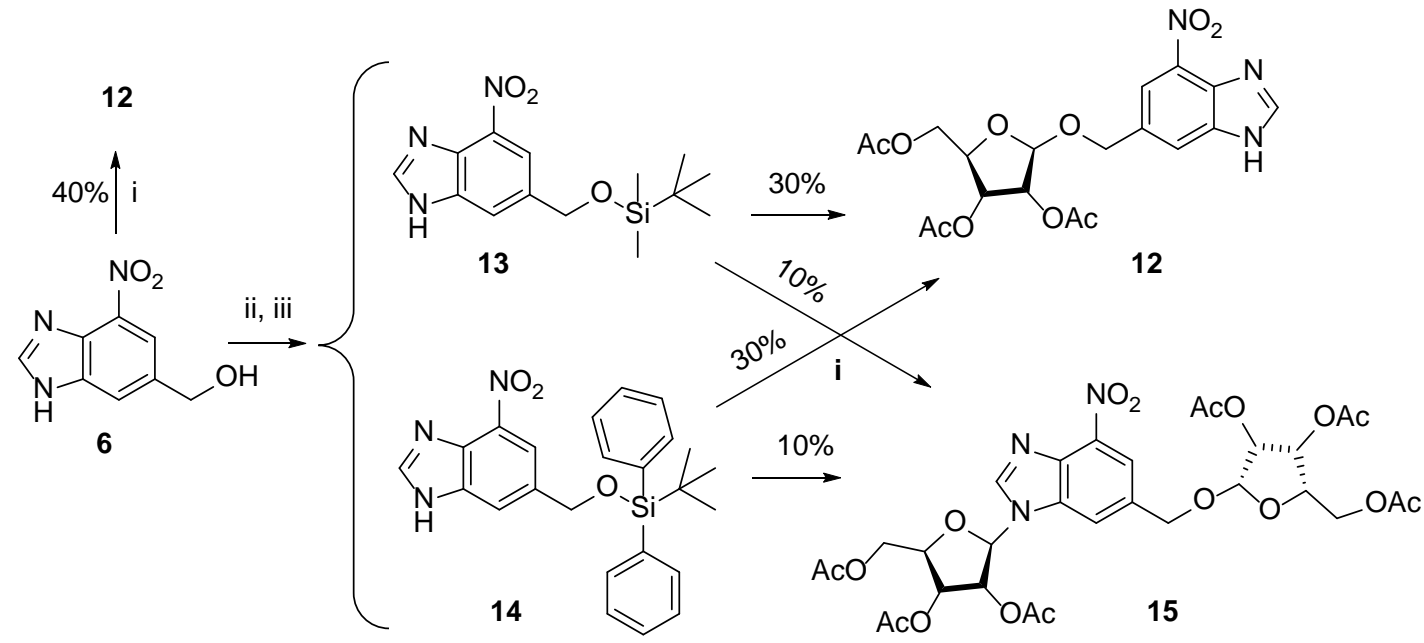

Scheme 2. Glycosylation reactions using the unprotected or protected heterocyclic base. Reagents and conditions: (i) dry acetonitrile, 1,2,3,5-tetra-O-acetyl- $\beta$-D-ribofuranose, tin (IV) chloride (1 M in dichloromethane (DCM)), room temperature (rt); (ii) dry acetonitrile, tert-butyldimethylsilyl chloride (TBDMSCl), imidazole, rt; (iii) dry acetonitrile, tert-butyldiphenylsilyl chloride (TBDPSCl), imidazole, rt.

We next considered whether using the milder glycosylation procedures as described in the silyl-Hilbert-Johnson or Vörbruggen reaction [20] would be advantageous, since the 2-hydroxymethyl 
protecting group was cleaved in the presence of stannic chloride, leading to the synthesis of $\mathbf{1 2}$. Using trimethylsilyl triflate (TMSOTf) as a Lewis acid for the glycosylation as described by C.P. Ashcroft [21] successfully afforded 19 (Scheme 3). We anticipated compound 19 to be the $N^{9}$-glycosylated dideazapurine derivative, but following careful corroboration using 2D NMR at different cut-offs (the correlation signals of $\mathrm{H}^{8}$ in the Heteronuclear Multiple Bond Correlation (HMBC) spectrum were missing in the original analysis), we confirmed the assignment as the $N^{7}$-glycosylated product. We hereto first identified the base $\mathrm{C}^{5}$ having three strong correlation signals with $H^{1}, H^{3}$ and $H^{8}$ in HMBC (Figure 2, purine-like numbering is used to highlight the analogy with adenine, see also Scheme 3; IUPAC nomenclature is used in the experimental part). This in turn allowed us to identify the $N^{7}$-glycosylation site $\left(N^{3}\right.$-imidazole-coupled sugar if considered as a benzimidazole derivative) via the 2D correlated signal of $H^{1^{\prime}}$ with $C^{5}$. X-ray crystallographic data afterwards (see Section 2.3) also confirmed the proposed $N^{7}$-dideaza-adenyl glycosylation site, with the electron density maps clearly indicating a flipped base having the exocyclic amine residing at the normal $N^{3}$-position.<smiles>O=[N+]([O-])c1cc(CO)cc([N+](=O)[O-])c1Cl</smiles>

8

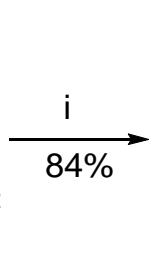

(1)<smiles></smiles>

17<smiles>CCCOCc1cc(N)c(N)c([N+](=O)[O-])c1</smiles>

18<smiles>CCO[O+]OCc1cc([N+](=O)[O-])c2nc[nH]c2c1</smiles>

13

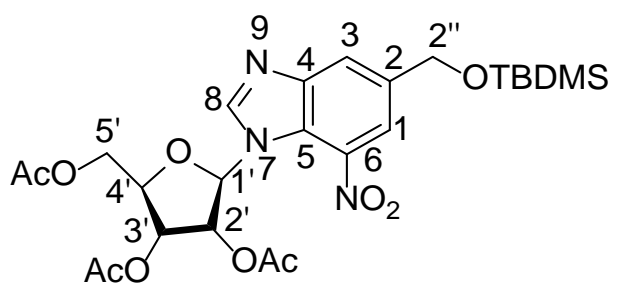

19

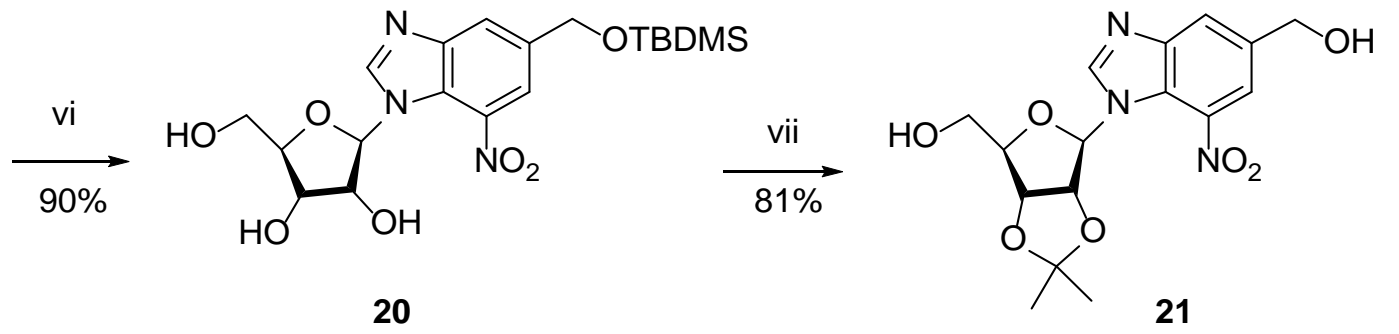

Scheme 3. Sugar-base coupling using a TBDMS-protected heterocycle. Reagents and conditions: (i) dry acetonitrile, TBDMSCl, imidazole, rt; (ii) methanol, aqueous ammonia, $65^{\circ} \mathrm{C}$; (iii) methanol/water (3:1), sodium sulfide, sodium hydrogen carbonate, $75^{\circ} \mathrm{C}$; (iv) triethyl orthoformate, formic acid, $145^{\circ} \mathrm{C}$, $6 \mathrm{~h}$; (v) 1,2-dichloroethane, 1,2,3,5-tetra-O-acetyl- $\beta$-D-ribofuranose, trimethylsilyl triflate (TMSOTf), $\mathrm{N}$-methylmorpholine, rt.; (vi) $7 \mathrm{~N}$ ammonia in methanol, $0{ }^{\circ} \mathrm{C}$ to $\mathrm{rt} 1 \mathrm{~h}$; (vii) $p$-toluenesulphonic acid (TSA), dry acetone, 2,2-dimethoxypropane (DMP), rt, $3 \mathrm{~h}$.

Improved solubility of compound $\mathbf{6}$ was observed following silylation prior to the sugar-base condensation step, which brought us to an improved synthetic route (Scheme 3) for the larger scale synthesis. Hence, TBDMS was introduced on 8 followed by amination, the selective reduction of one of the nitro functionalities, cyclization and glycosylation to finally obtain 19 . The acetate protection of 19 was removed using $7 \mathrm{~N}$ ammonia solution in methanol to afford 20 with an almost quantitative yield. Having coupled the sugar and the heterocyclic moiety, the next phase of the synthesis required the elaboration of the primary hydroxyl of the sugar part for sulfamoylation. The formation of the 
acetonide 21 was accomplished with $p$-toluenesulphonic acid in a mixture of acetone in the presence of two equiv. of 2,2-dimethoxypropane (DMP) [5]. However, the undesired concomitant cleavage of the silyl protecting group of the base moiety obviously generates a selectivity problem for the next sulfamoylation reaction, catapulting us back to the start.
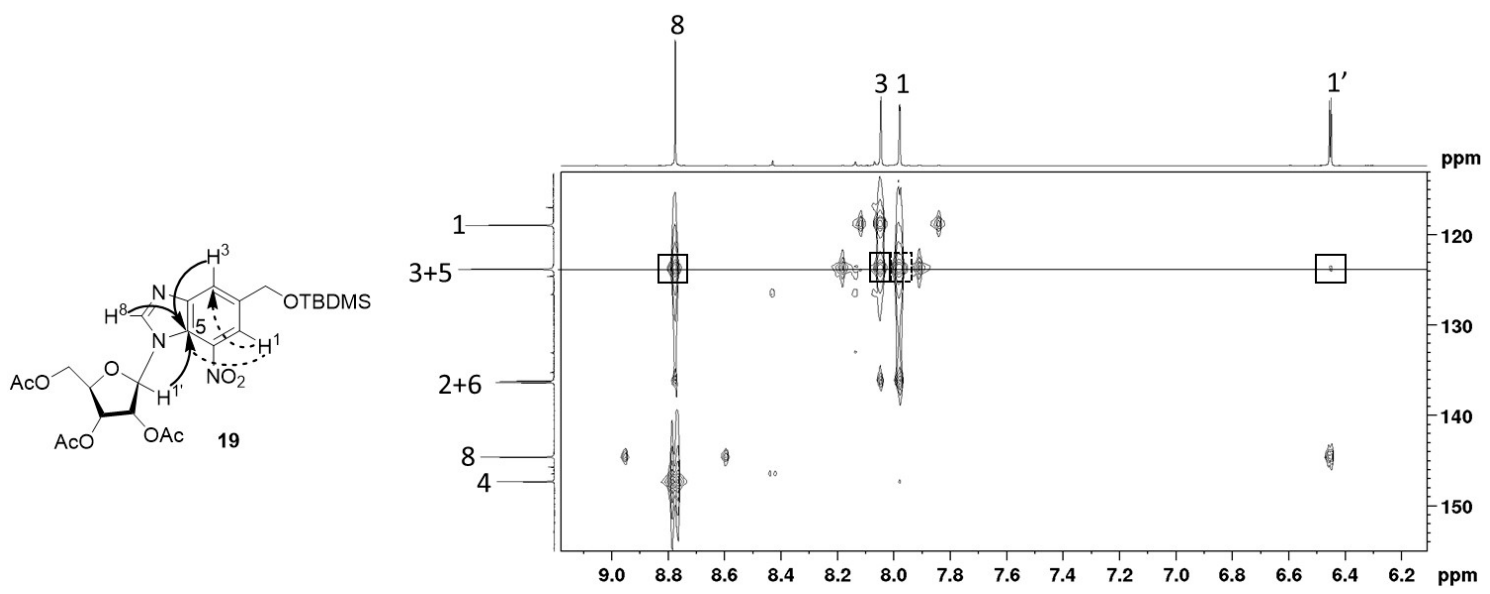

Figure 2. Decisive correlations with C5 on the N7-linked base in compound 19 are indicated by bold arrows in the structure on the left and boxed in the HMBC spectrum. Correlations indicated with a dashed arrow are overlapping (box in dashed lines). Labels correspond to assignments in proton and carbon dimensions.

The encountered incompatibility finally led us to the use of the more stable benzyl group for the protection of the base moiety, and the synthesis of benzyl-protected 6-hydroxymethyl4-nitro-benzimidazole (25) starting from 8 (Scheme 4). The benzyl protection of the primary alcohol of 8 using established procedures [22] to afford $\mathbf{2 2}$ was followed by amination, the selective reduction of one nitro group, cyclization, glycosylation and the hydrolysis of the acetate groups to give compounds $23,24,25,26$ and 27, respectively. The acetonide protection of 27 was performed in analogy to 21 while preserving the benzyl protecting group. The direct sulfamoylation of 28 with sulfamoyl chloride (prepared in situ by the reaction of chlorosulfonyl isocyanate with formic acid) led to the synthesis of 29 [23]. The 2D NMR of compound 29 (Figure 3) clearly showed an interaction between $H^{1^{\prime}}$ and $C^{5}$ in $\mathrm{HMBC}$, indicating the $\mathrm{N}^{7}$-glycosylated $\mathbf{2 6}$ (using purine numbering) to be the major product upon glycosylation under Hilbert-Johnson conditions. No minor products were isolated.

The aminoacyl-sulfamate analogues $30 a-f$ were obtained by the coupling of the respective $\mathrm{N}$-hydroxysuccinimide ester of appropriately protected amino acids with the key sulfamoyl compound 29 using DBU as a base in DMF (Scheme 4). The removal of the 2-hydroxymethyl-protecting benzyl moiety concomitant with the deprotection of the amino acid (serine and tyrosine specifically), as well as the reduction of the 6-nitro group, was accomplished by reductive hydrogenation with $10 \%$ Degussa-type $\mathrm{Pd} / \mathrm{C}$. Surprisingly, via the NMR and mass spectrometric analysis of compound 31a, we unexpectedly observed a dehydroxylated compound (with concomitant reduction to a C2-methylated base moiety). Benzylic alcohols can be reduced to the corresponding alkyl groups under simple hydrogenolysis conditions, for instance, with hydrogen gas using $\mathrm{Pd} / \mathrm{C}$ as a catalyst. This happens in a limited number of cases upon the cleavage of benzyl ethers, a common protecting group. Of all six Pd/C-treated compounds 31a-f, only the glycine analogue 31a proved to be reduced. Tert-butyloxycarbonyl and acetonide groups were cleaved using a TFA/water (5:2) mixture to afford the final compounds 32a-f (aaS7HMDDA and GlyS7MDDA) [6]. All the compounds synthesized in this project were unambiguously characterized by one or more means of ${ }^{1} \mathrm{H},{ }^{13} \mathrm{C}$ NMR spectroscopy and electrospray ionization (ESI)-MS. 
<smiles>[Z20]c1c(N)cc(COCc2ccccc2)cc1[N+](=O)[O-]</smiles>

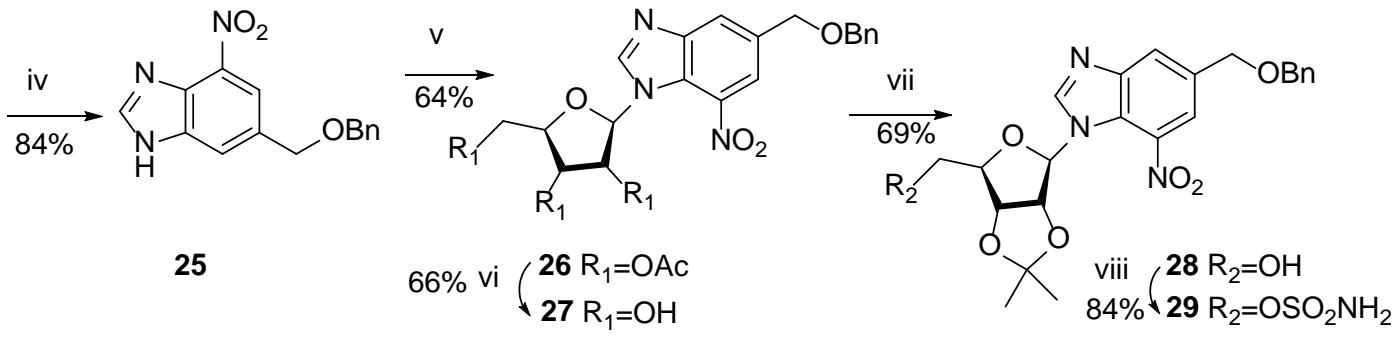<smiles></smiles>

30a-32a: $\mathrm{R}=\mathrm{H}$; 30b: $\mathrm{R}=\mathrm{CH}_{2} \mathrm{C}_{6} \mathrm{H}_{4}{ }^{-} p-\mathrm{OBn}, \mathbf{3 1 b}-\mathbf{3 2 b}$ :

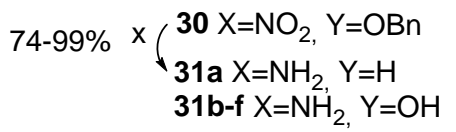

$\mathrm{R}=\mathrm{CH}_{2} \mathrm{C}_{6} \mathrm{H}_{4}^{-} p-\mathrm{OH}$; 30c: $\mathrm{R}=\mathrm{CH}_{2} \mathrm{OBn}, 31 \mathrm{c}-32 \mathrm{c}: \mathrm{R}=\mathrm{CH}_{2} \mathrm{OH}$; 30d-31d: $\mathrm{R}=\mathrm{CH}_{2} \mathrm{COO}-\mathrm{t}-\mathrm{Bu}$, 32d: $\mathrm{R}=\mathrm{CH}_{2} \mathrm{COOH}$ 30e-32e: $\mathrm{R}=\mathrm{CH}_{2} \mathrm{CH}\left(\mathrm{CH}_{3}\right)_{2} ;$ 30f-32f: $\mathrm{R}=\mathrm{CH}\left(\mathrm{CH}_{3}\right) \mathrm{CH}_{2} \mathrm{CH}_{3}$ 32a: $Y=H$, 32b-f: $Y=O H$

Scheme 4. Final optimized route leading to the aaS7HMDDA analogues. Reagents and conditions: (i) dry 1,4-dixone, benzyl 2,2,2-trichloroacetimidate, trifluoromethane-sulfonate, rt; (ii) methanol, aqueous ammonia, $65^{\circ} \mathrm{C}$; (iii) methanol/water (3:1), sodium sulfide, sodium hydrogen carbonate, $75{ }^{\circ} \mathrm{C}$; (iv) triethyl orthoformate, formic acid, $145{ }^{\circ} \mathrm{C}, 6 \mathrm{~h}$; (v) 1,2-dichloroethane, 1,2,3,5-tetra$O$-acetyl- $\beta$-D-ribofuranose, TMSOTf, $N$-methylmorpholine, rt; (vi) $7 \mathrm{~N}$ ammonia in methanol, $0{ }^{\circ} \mathrm{C}$ to $\mathrm{rt}, 1 \mathrm{~h}$; (vii) $p$-TSA, dry acetone, DMP, rt, $3 \mathrm{~h}$; (viii) $\mathrm{NH}_{2} \mathrm{SO}_{2} \mathrm{Cl}$, acetonitrile, rt, overnight; (ix) Boc-aa-(tBu/Bn)-OSu, 1,8-Diazabicyclo[5.4.0]undec-7-ene (DBU), dry dimethylformamide (DMF), rt, overnight; (x) Pd/C, methanol, $\mathrm{H}_{2}$ atm. rt, overnight; (xi) trifluoroacetic acid (TFA)/ $\mathrm{H}_{2} \mathrm{O}, 5: 2$ (v/v).

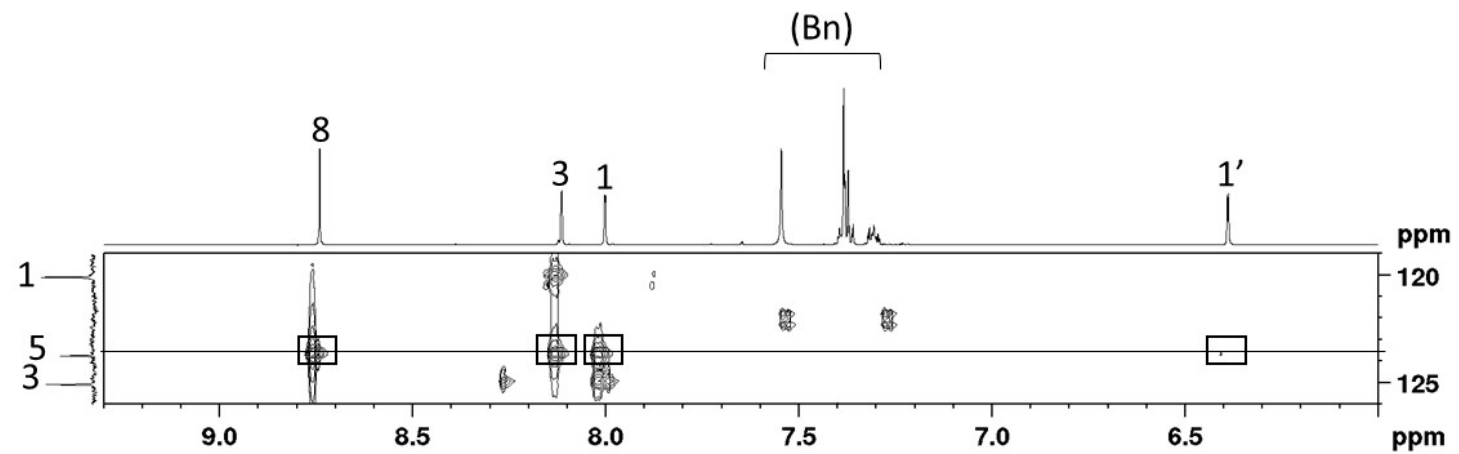

Figure 3. Decisive correlations with C5 on the N7-linked base in compound 29 are boxed in the HMBC spectrum. Labels correspond to assignments in proton and carbon dimensions.

\subsection{Measurement of In Vitro Enzymatic Inhibitory Activity with Purified E. coli aaRSs}

The five aaS7HMDDA analogues (the glycine derivative was left out) were evaluated for their ability to inhibit the aaRS-catalyzed aminoacylation of tRNA using the corresponding isolated E. coli 
aaRS (Figure 4). In the case of the class I-targeting compounds, low-nanomolar $K_{i}^{a p p}$ were obtained for the 7HMDDA derivatives $32 \mathbf{e}-\mathbf{f}$ and $1.2 \mu \mathrm{M}$ for $32 \mathbf{b}$ targeting TyrRS. While these values reflect high affinity for the target enzymes, the inhibition is 5 to 420 -fold lower compared to that with the original aaSA analogue (Table 1). This contrasts with the inhibitory activity noted for the congeners targeting class II AspRS and SerRS, as only 9\% and 54\% inhibitory activity, respectively, was observed at a $200 \mu \mathrm{M}$ inhibitor concentration (Figure $4 \mathrm{~A}$ ).

A

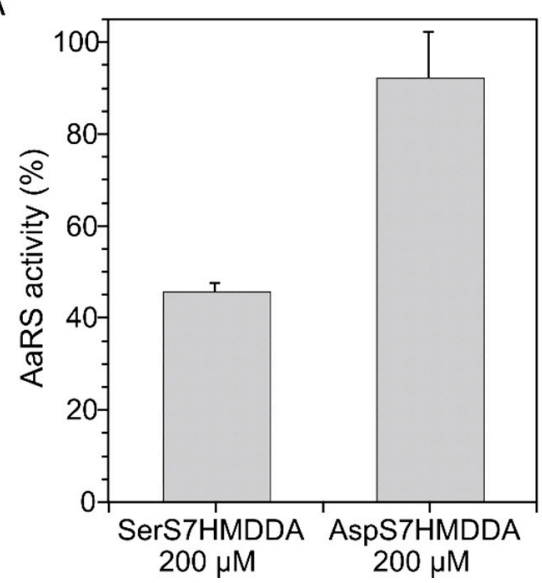

B

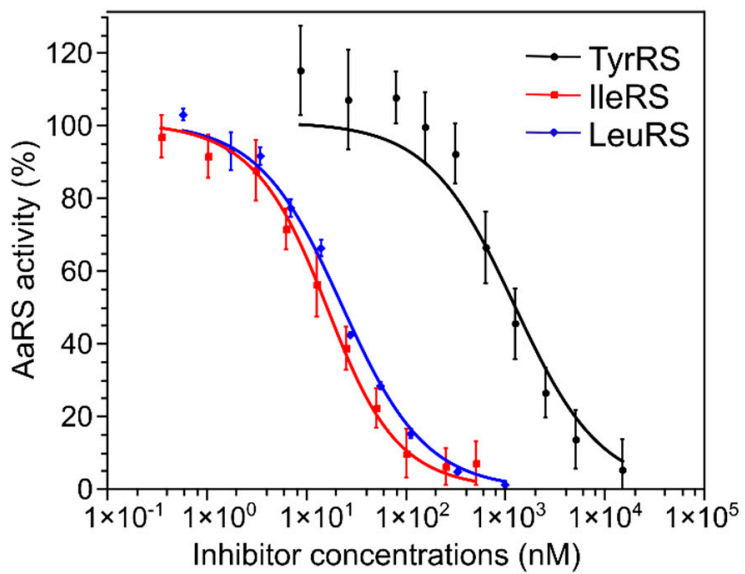

Figure 4. In vitro enzymatic inhibitory activity. (A): Inhibitory activity of HMDDA derivatives targeting SerRS and AspRS (class II enzymes) at high concentration. (B): Dose-response curves of HMDDA derivatives targeting class I enzymes IleRS, LeuRS and TyrRS. The activity of each enzyme is reported as a percentage value relative to that measured in the absence of inhibitor. The presented fit of the measured points was calculated using the Greco-Hakala equation [24]. Averages of three experiments with SD error bars are shown.

Table 1. $K_{i}^{a p p}$ values of the aminoacylated sulfonamide nucleosides for the respective class I enzymes are given in $\mathrm{nM}$.

\begin{tabular}{ccc}
\hline Class I aaRSs & $\boldsymbol{K}_{\boldsymbol{i}}^{a p p}(\mathbf{a a S A}){ }^{*}$ & $\boldsymbol{K}_{\boldsymbol{i}}^{a p p}($ aaS7HMDDA $)$ \\
\hline IleRS & $1.92 \pm 4.0$ & $10.8 \pm 0.8$ \\
LeuRS & $0.14 \pm 0.10$ & $21.5 \pm 1.2$ \\
TyrRS & $2.93 \pm 1.2$ & $1232.2 \pm 239.1$ \\
\hline * The $K_{i}^{a p p}$ values for the adenosine derivatives were taken from our prior work [3]
\end{tabular}

\subsection{Crystallographic Analysis}

To further investigate the structure-activity relationship (SAR), X-ray crystal structures of an aaRS in complex with the corresponding synthesized HMDDA analogues were determined (Figure 5 and Table 2). As shown in Figure 5, the compound was unambiguously built inside the active site of tRNA synthetase according to the electron density map, which confirmed the conformation of the flipped base. With the present modification, in most cases, the amine group occupies the place where the $N^{3}$ of adenine is normally residing and mimics its interaction with the protein. This results in the HMDDA base rotating towards the ribose when compared to the conformation of the canonical bound adenine (Figure 5).

In our previous work, we discussed in detail the interactions between the adenine base and the respective class I and class II enzymes [3]. In the case of class I aaRSs, only two polar interactions with the base are consistently observed for the different aaRS:aaSA complex structures, mediated by the interaction of the protein backbone atoms with the $N^{1}$ and $N^{6}$ atoms of adenine. In this work, the flipped base loses part of these important interactions, providing a good rationale for their lower activity compared with aaSA (Figure 5A,B). As seen in LeuRS, the amine group of the HMDDA 
base is involved in a H-bond with the side chain of Gln580, which originally interacts with $\mathrm{N}^{3}$ of adenine, but loses a stacking interaction with the side chain of Met582 and the polar contact with the backbone of Met635 as observed in the equivalent adenine congener (Figure 5A). In addition, the hydroxymethyl group of the base makes H-bonds with backbone atoms of Val583 in LeuRS or Ile228 in TyrRS, respectively.

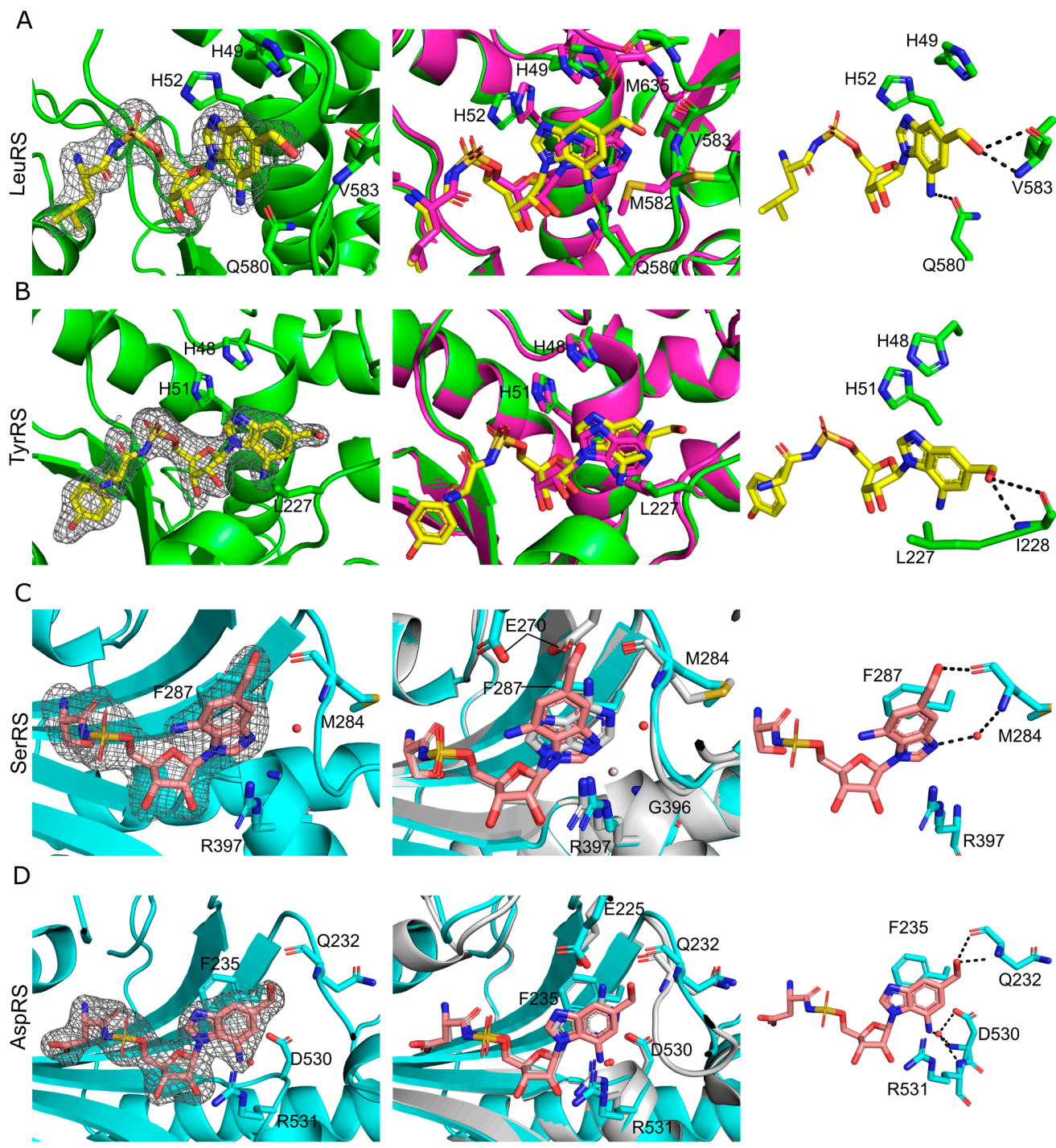

Figure 5. X-ray structures of aaS7HMDDA bound to the corresponding aaRS of class I (green) and class II (cyan). (A) N. gonorrhoeae LeuRS in complex with LeuS7HMDDA; (B) E. coli TyrRS in complex with TyrS7HMDDA; (C) K. pneumoniae SerRS in complex with SerS7HMDDA; (D) T. thermophilus AspRS in complex with AspS7HMDDA. Left: electron density map for the ligand; Middle: superposition of aaS7HMDDA and aaSA bound structures; Right: protein-aaS7HMDDA interactions. Protein structures are presented as cartoon representations. The ligand and interacting residues are shown in stick representations. A conserved structured water molecule in SerRS and AspRS is shown as a sphere.

For class II aaRSs, the adenine makes numerous interactions with active site residues, with the $N^{1}, N^{3}$ and $N^{6}$ all making H-bond interactions with conserved features shared amongst all class II aaRS members. The interaction between the $\mathrm{N}^{3}$ of adenine with the conserved water molecule for class II aaRS enzymes is crucial for the recognition of aaSAs by the corresponding enzymes [25]. It was hypothesized that the flipped exocyclic amine moiety of HMDDA should be able to mimic this specific interaction. However, in the case of SerRS, the base moiety adopts the syn-conformation relative to the 
ribose defined by the torsion angle $\left(O^{4^{\prime}}-C^{1^{\prime}}-N^{7}-C^{8}\right)$ of $-124^{\circ}$, while the base bound in the active site of class I LeuRS and TyrRS and class II AspRS remains in the anti-conformation (Figure 5). In this specific syn conformation in SerRS, the hydroxymethyl group of the base forms a direct H-bond with the carbonyl oxygen of Met284, and N9 makes an indirect contact with the backbone nitrogen of Met284 via a water bridge (Figure 5C). Despite the HMDDA base making some interactions with surrounding protein residues, compared with the adenine congener, the lack of H-bonds mediated by $N^{6}$ and $N^{3}$ of adenine with the conserved Glu270 and structural water molecule leads to a detrimental effect on its inhibitory activity. Although in the case of AspRS, the position of the HMDDA base overlaps with the natural adenine base, all the original interactions of the $N^{6}$ as seen for the equivalent aaSA are still lost with AspS7HMDDA, similarly to what is seen with SerRS (Figure 5D). Furthermore, the $\mathrm{N}^{6}$ amine group creates an unfavorable bond with the class II conserved structured water. This could explain the more significant decrease in inhibitory activity compared with that seen for class I aaRSs.

Table 2. Data collection and refinement statistics for the crystal structures of aaRS in complex with aaS7HMDDA.

\begin{tabular}{|c|c|c|c|c|}
\hline & SerRS-SerS7HMDDA & LeuRS-LeuS7HMDDA & AspRS-AspS7HMDDA & TyrRS-TyrS7HMDDA \\
\hline \multicolumn{5}{|l|}{ Data collection } \\
\hline & $19.96-2.18$ & $56.25-2.25$ & $79.53-2.15$ & $52.6-1.998$ \\
\hline Resolution range (A) & $(2.26-2.18)$ & $(2.33-2.25)$ & $(2.23-2.15)$ & $(2.07-1.998)$ \\
\hline Space group & $P 4_{3} 2_{1} 2$ & $P 2_{1} 2_{1} 2_{1}$ & $P 12_{1} 1$ & $P 12_{1} 1$ \\
\hline \multirow{2}{*}{ Unit cell } & 84.784 .7229 .9 & 49.281 .0225 .0 & 82.3112 .588 .3 & 82.265 .191 .090 \\
\hline & 909090 & 909090 & 90104.990 & 101.390 \\
\hline Total reflections & $537,775(53,341)$ & $565,139(56,028)$ & $311,929(31,077)$ & $229,644(22,423)$ \\
\hline Unique reflections & $44,514(4326)$ & $43,755(4274)$ & $83,442(8289)$ & $63,719(6342)$ \\
\hline Multiplicity & $12.1(12.3)$ & $12.9(13.1)$ & $3.7(3.7)$ & $3.6(3.5)$ \\
\hline Completeness (\%) & $99.50(99.49)$ & 99.99 (100.00) & $98.84(98.57)$ & $99.21(99.15)$ \\
\hline Mean $I / \sigma(I)$ & $15.45(2.01)$ & $10.91(2.00)$ & $10.57(2.37)$ & $7.39(1.28)$ \\
\hline Wilson B factor $\left(\AA^{2}\right)$ & 50.0 & 41.6 & 46.49 & 29.66 \\
\hline$R_{\text {merge }}$ & $0.0828(1.198)$ & $0.1624(1.407)$ & $0.06744(0.535)$ & $0.1068(0.971)$ \\
\hline$R_{\text {meas }}$ & $0.0866(1.25)$ & $0.1692(1.465)$ & $0.07833(0.62)$ & $0.1253(1.14)$ \\
\hline$R_{\text {pim }}$ & $0.02507(0.3546)$ & $0.04709(0.4034)$ & $0.03934(0.3139)$ & $0.06464(0.5966)$ \\
\hline $\mathrm{CC}_{1 / 2}$ & $0.999(0.941)$ & $0.998(0.713)$ & $0.996(0.837)$ & $0.997(0.686)$ \\
\hline \multicolumn{5}{|l|}{ Refinement } \\
\hline Reflections used for $R_{\text {free }}$ & $2044(206)$ & 2006 (198) & 2055 (217) & $2465(245)$ \\
\hline$R_{\text {work }}$ & $0.1889(0.2867)$ & $0.1873(0.2827)$ & $0.1831(0.2553)$ & $0.2028(0.3036)(0.3014)$ \\
\hline$R_{\text {free }}$ & $0.2163(0.2789)$ & $0.2355(0.3466)$ & $0.2304(0.2927)$ & $0.2531(0.3343)(0.3307)$ \\
\hline Number of non-H atoms & 3511 & 6732 & 9374 & 6985 \\
\hline Macromolecules & 3347 & 6476 & 8998 & 6428 \\
\hline Ligands & 31 & 33 & 76 & 74 \\
\hline Solvent & 118 & 213 & 300 & 481 \\
\hline Protein residues & 421 & 843 & 1153 & 826 \\
\hline RMS bonds ( $\mathrm{A})$ & 0.012 & 0.004 & 0.012 & 0.007 \\
\hline RMS angles $\left({ }^{\circ}\right)$ & 1.56 & 0.65 & 1.16 & 0.82 \\
\hline Ramachandran favored (\%) & 97.11 & 96.65 & 96.41 & 97.44 \\
\hline Ramachandran allowed (\%) & 2.89 & 3.23 & 3.32 & 2.46 \\
\hline Rotamer outliers (\%) & 1.4 & 0.16 & 2.67 & 0.12 \\
\hline Clashscore & 1.34 & 4.28 & 5.52 & 4.56 \\
\hline Average B-factor $\left(\AA^{2}\right)$ & 61.19 & 49.49 & 69.85 & 41.46 \\
\hline Protein & 61.22 & 49.69 & 70.08 & 41.61 \\
\hline Inhibitor & 52.88 & 36.44 & 59.50 & 30.65 \\
\hline Solvent & 60.56 & 45.51 & 55.33 & 41.20 \\
\hline
\end{tabular}

Statistics were generated using Phenix [26]; values in parenthesis correspond to the highest resolution shell.

\section{Discussion}

There is a clear precedent in the synthesis and application of deazapurines in medicinal chemistry $[5,27,28]$. Within our research group, Gadakh. et al. [6] reported one deazapurine 5'-O( $\mathrm{N}$-isoleucyl)sulfamoyl-1,3-dideazaadenosine as an IleRS inhibitor, but unfortunately, there was a significant loss of inhibitory activity compared with the IleSA compound. However, Lee et al. [7] reported a small cavity around the C2-position of adenine based on their docking study of IleSA's interaction with the IleRS enzyme, suggesting to us that introducing a 2-hydroxymethyl group probably could improve the interaction with the targeted enzymes. Based on this assumption, we planned to synthesize a series of six compounds using this 1,3-dideaza-2-hydroxymethyladenine scaffold and targeting representatives of both classes of aaRSs. The removal of the $N^{3}$ atom as in 3-deazaadenine 
should enhance the chemical stability, and according to modelling, the inhibitory activity should improve via interactions of the Supplementary Materials hydroxymethyl moiety with the target enzyme. In combination with 3-deazaadenosine [3], this scaffold should provide us with a more comprehensive understanding of the SAR properties of the base moiety.

The synthesis of the target compounds proved to be not straightforward. At first, we tried to carry out the reactions without protecting the carboxylic acid group of 4-chloro-benzoic acid but failed to yield the desired compound $\mathbf{6}$ (as shown in Scheme 1), while also, the yield for the cyclization step was low. Secondly, we applied another synthetic route where the reduction of the carboxylic group was carried out at the second step, and we successfully obtained the desired compound $\mathbf{6}$ with a moderate yield. However, when applying the standard glycosylation procedure, the sugar moiety preferentially coupled to the hydroxymethyl group as shown in Scheme 2. Upon the protection of the hydroxyl moiety with tert-butyldimethylsilyl chloride (TBDMSCl) immediately following the reduction of the carboxylic group (Scheme 3), we managed to synthesize the base with an increased overall yield and also succeeded in the glycosylation of the desired heterocycle. Unfortunately, this TBDMS protection was cleaved when trying to protect the $2^{\prime}, 3^{\prime}$-hydroxyl moieties with the isopropylidene group, and obviously, the resulting presence of two primary alcohols provides a selectivity issue in the following sulfamoylation step. We finally opted for the more stable benzyl group for the protection of the base moiety and successfully obtained the targeted final compounds (Scheme 4). The benzyl group was cleaved simultaneously with the reduction of the nitro group using hydrogenation with a Pd/C catalyst. Surprisingly, only for 32a, the anomalous reduction of the benzyl ether afforded a methyl group instead of the expected hydroxymethyl moiety, for which we have no explanation but which seems to be related to the unbranched glycine.

The $N^{7}$-1,3-dideazapurine glycosylation site was unexpected but was firmly corroborated via extensive HMBC correlation studies, and further confirmed by the X-ray structures of aaRSs in complex with their corresponding inhibitors. The biological activity of aaSHMDDA analogues showed that all the newly synthesized compounds were less potent than the respective aaSAs. However, while inhibitors targeting class I aaRSs still exhibit lower nanomolar inhibitory activity, especially for class I IleRS and LeuRS, the respective compounds targeting class II enzymes lost their inhibitory activity even at the higher concentration of $200 \mu \mathrm{M}$.

To provide further insight into the SAR of the molecules, the X-ray crystal structures of the compounds with their respective aaRSs were solved. When comparing the structures of the aaRSs in complex with their corresponding aaS7HMDDA analogues, it is clear that this flipped base only can replicate the interactions of $N^{3}$ in adenine by the amine in aaS7HMDDA but loses almost all the important interactions generated by $N^{1}$ and $N^{6}$ in adenine due to the flipped orientation of the base. The Supplementary Materials hydroxymethyl moiety obviously is not located at the originally intended position but makes polar interactions with the backbone of contacting protein residues. For both LeuRS and TyrRS, we note these H-bonds mediated by the hydroxymethyl moiety, and for IleRS, crystallographic data are not available.

Nevertheless, IleS7HMDDA (32f) is only five times less inhibitory than the well-known inhibitor IleSA, which surprisingly is 10-fold better compared to the 3-deaza derivative IleS3DA [3]. The compound also outperforms the pyrimidine analogues previously reported [25]. By contrast, the inhibitory activity for the leucine analogue 32e is analogous to its pyrimidine congeners, but for LeuRS, the LeuS3DA congener almost matched the strong activity of LeuSA. While TyrS7HMDDA was about 400 times less inhibitory compared to TyrSA, the 3DA and the uracil analogue only gave 10 -fold and 15-fold reductions in activity, respectively, while the cytosine congener also suffered a 400-fold decreased inhibitory activity. It is clear that the subtle differences between these class I aaRSs structures can have significantly different effects on the inhibitory activity of the corresponding inhibitors sharing similar scaffolds. However, in class II aaRSs, two different base conformations were observed, where the base adopts an anti-conformation in AspRS as seen in class I aaRSs but a syn conformation in SerRS. This is likely the result of the distinct flexibility of their motif-2 loop regions. 
A comparison of ligand-free and ligand-bound states shows that the motif-2 loop is in a relative fixed position (a closed conformation) in SerRS independently of inhibitors binding, while this loop region in AspRS is more dynamic, which has been described in detail in our previous work [29]. In the holo-enzyme of AspRS, the motif-2 loop region adopts an open conformation and only changes to the closed conformation upon the binding of adenine-containing compounds. Both HMDDA base conformations in SerRS and AspRS either lose the additional conserved structural water-mediated H-bonds as observed for the $N^{3}$ of adenine or make unfavorable interactions with structured water due to the presence of protons at the $\mathrm{N}^{6}$-amine moiety. This could further explain why this scaffold is more disruptive for binding for class II than for class I inhibitors. This highlights again that the extensive modification of the heterocyclic base can be tolerated, especially for the inhibition of class I aaRS enzymes, as highlighted as well with the strongly inhibiting pyrimidine nucleosides reported by Nautiyal et al. [25].

\section{Conclusions}

A series of six $N^{7}$-glycosylated aminoacyl sulfamoyl-2-hydroxymethyl-1,3-dideazaadenosine analogues were synthesized with three compounds, each targeting both classes of aaRSs. An optimized chemical route hereto was elaborated to obtain the desired heterocyclic base, and the glycosylation site was firmly established via extensive 2D NMR and crystallographic studies. In vitro evaluation using purified aaRS enzymes showed, especially, class I-targeting compounds to be active, with, in particular, 32e and 32f displaying nanomolar inhibitory activity against LeuRS and IleRS, respectively. Structural analysis showed the flipped 2-hydroxymethyl-1,3-dideazaadenine base is partially mimicking the interactions of adenine within both series of aaRS enzymes.

\section{Experimental Section}

\subsection{Reagents and Methods}

The reagent qualities and sources and general methods were as described before $[3,25]$.

\subsubsection{4-Chloro-3,5-Dinitrobenzoic Acid (2)}

4-chloro-benzoic acid 1 (20 g, $0.128 \mathrm{~mol})$ was dissolved in $\mathrm{H}_{2} \mathrm{SO}_{4}(\mathrm{~d}=1.835 \mathrm{~g} / \mathrm{mL}, 300 \mathrm{~mL})$ at $80{ }^{\circ} \mathrm{C}$, and $\mathrm{KNO}_{3}(66 \mathrm{~g}, 0.65 \mathrm{~mol})$ was added. The reaction mixture was heated to $125^{\circ} \mathrm{C}$ using a high-pressure flask and kept for $2 \mathrm{~h}$, after which the reaction was cooled to rt and poured onto ice. The yield of title compound 2 was $28 \mathrm{~g}(89 \%)[16] .{ }^{1} \mathrm{H}$ NMR $\left(300 \mathrm{MHz}, \mathrm{DMSO}-d_{6}\right) \delta=14.29(\mathrm{~s}, 1 \mathrm{H})$, 8.76 (s, 2H). ${ }^{13} \mathrm{C}$ NMR (75 MHz, DMSO-d6) $\delta 163.61,149.06,132.20,128.70,122.80$. HRMS (ESI): $m / z$ calcd. for $\mathrm{C}_{7} \mathrm{H}_{2} \mathrm{ClN}_{2} \mathrm{O}_{6}[\mathrm{M}-\mathrm{H}]^{-}$: 244.9607; found, 244.9607.

\subsubsection{4-Amino-3,5-Dinitrobenzoic Acid (3)}

Compound $2(20 \mathrm{~g}, 81 \mathrm{mmol})$ was dissolved in methanol $(100 \mathrm{~mL})$, and aqueous $24 \% \mathrm{NH}_{3}(120 \mathrm{~mL})$ was gradually added. The reaction mixture was stirred at $\mathrm{rt}$ for $2.5 \mathrm{~h}$, refluxed for $3 \mathrm{~h}$ and left at $\mathrm{rt}$ for around $14 \mathrm{~h}$. The precipitate that formed was filtered off, and the filtrate was evaporated to dryness. Water $(10 \mathrm{~mL})$ and $\mathrm{HCl}(10 \mathrm{~mL})$ were added to the solid residue, which was combined with the precipitate. After stirring for $10 \mathrm{~min}$, the precipitate was filtered off and washed with water till washings showed neutral. The yield of 4-amino-3,5-dinitrobenzoic acid 3 was $18 \mathrm{~g}(98 \%)$ [16]. ${ }^{1} \mathrm{H} \mathrm{NMR}$ (300 MHz, Acetone- $\left.d_{6}\right) \delta=9.16-9.01(\mathrm{~m}, 3 \mathrm{H}), 9.01-8.84(\mathrm{~s}, 2 \mathrm{H}) .{ }^{13} \mathrm{C}$ NMR $\left(75 \mathrm{MHz}\right.$, Acetone- $\left.d_{6}\right) \delta$ 163.49, 143.33, 134.76, 133.75, 128.17, 115.39. HRMS (ESI): $m / z$ calcd. for $\mathrm{C}_{7} \mathrm{H}_{4} \mathrm{~N}_{3} \mathrm{O}_{6}[\mathrm{M}-\mathrm{H}]^{-}: 226.0105$; found, 226.0100 .

\subsubsection{3,4-Diamino-5-Nitrobenzoic Acid (4)}

A suspension of freshly made compound $3(10 \mathrm{~g}, 44 \mathrm{mmol})$ in water $(200 \mathrm{~mL})$ was heated to $60^{\circ} \mathrm{C}$ with stirring for about $10 \mathrm{~min}$. To this suspension was then added a solution of sodium sulfide $(11.2 \mathrm{~g}$, 
anhydrous) and sodium bicarbonate $(11.5 \mathrm{~g})$ in water $(250 \mathrm{~mL})$. The reaction mixture was stirred at $75^{\circ} \mathrm{C}$ for $1 \mathrm{~h}$ and left to cool overnight, after which it was concentrated and subjected to silica gel column chromatography to give a deep red solid compound 4 with a yield of $74 \%$ [17]. ${ }^{1} \mathrm{H}$ NMR $\left(300 \mathrm{MHz}, \mathrm{DMSO}-d_{6}\right) \delta 12.56(\mathrm{~s}, 1 \mathrm{H}), 7.98(\mathrm{~d}, J=1.9 \mathrm{~Hz}, 1 \mathrm{H}), 7.40(\mathrm{~s}, 2 \mathrm{H}), 7.30(\mathrm{~d}, J=1.9 \mathrm{~Hz}, 1 \mathrm{H})$, $5.47(\mathrm{~s}, 2 \mathrm{H}) .{ }^{13} \mathrm{C}$ NMR $\left(75 \mathrm{MHz}\right.$, DMSO- $\left.d_{6}\right) \delta 166.71,138.09,137.74,130.25,117.66,116.01,115.78$. HRMS (ESI): $m / z$ calcd. for $\mathrm{C}_{7} \mathrm{H}_{6} \mathrm{~N}_{3} \mathrm{O}_{4}[\mathrm{M}-\mathrm{H}]^{-}:$196.0364; found, 196.0367 .

\subsubsection{4-Nitro-1H-Benzo[d]imidazole-6-Carboxylic Acid (5)}

Compound 4 ( $2 \mathrm{~g}, 10.15 \mathrm{mmol})$ was refluxed for $6 \mathrm{~h}$ in $50 \mathrm{~mL}$ of formic acid. The reaction mixture was concentrated, and then, $10 \mathrm{~mL}$ of $30 \%$ aqueous $\mathrm{NaOH}$ was slowly added to the residue. The resulting suspension was portioned between $30 \mathrm{~mL}$ of ethyl acetate and $20 \mathrm{~mL}$ of water 3 times; the combined ethyl acetate layer was concentrated and subjected to a silica gel column to obtain $600 \mathrm{mg}$ of 5 with a $29 \%$ yield [30]. ${ }^{1} \mathrm{H}$ NMR $\left(300 \mathrm{MHz}, \mathrm{DMSO}-d_{6}\right) \delta=13.54(\mathrm{~s}, 2 \mathrm{H}), 8.64-8.57(\mathrm{~m}, 2 \mathrm{H})$, $8.56(\mathrm{~d}, J=1.5 \mathrm{~Hz}, 1 \mathrm{H}) .{ }^{13} \mathrm{C}$ NMR $\left(75 \mathrm{MHz}, \mathrm{DMSO}-d_{6}\right) \delta 166.25,147.16,133.43,126.95,124.45,119.75$. HRMS (ESI): $m / z$ calcd. for $\mathrm{C}_{8} \mathrm{H}_{4} \mathrm{~N}_{3} \mathrm{O}_{4}[\mathrm{M}-\mathrm{H}]^{-}:$206.0207; found, 206.0208 .

\subsection{5. (4-Nitro-1H-Benzo[d]imidazol-6-yl)-Methanol (6)}

Compound 11 (160 mg, $0.72 \mathrm{mmol})$ was dissolved in methanolic ammonia $(7 \mathrm{~N}, 15 \mathrm{~mL})$ and stirred at $25^{\circ} \mathrm{C}$ for $1.5 \mathrm{~h}$. After TLC showed the completion of the reaction, the mixture was concentrated, and $10 \mathrm{~mL}$ of DCM was added. Undissolved solid compound was filtered, and $123 \mathrm{mg}$ of the title product 6 was collected with a yield of $88 \% .{ }^{1} \mathrm{H}$ NMR $\left(300 \mathrm{MHz}, \mathrm{DMSO}-d_{6}\right) \delta 8.43(\mathrm{~s}, 1 \mathrm{H})$, $8.14(\mathrm{~d}, J=1.3 \mathrm{~Hz}, 1 \mathrm{H}), 8.06(\mathrm{~d}, J=1.3 \mathrm{~Hz}, 1 \mathrm{H}), 4.70(\mathrm{~s}, 2 \mathrm{H}) .{ }^{13} \mathrm{C}$ NMR $\left(75 \mathrm{MHz}, \mathrm{DMSO}-d_{6}\right) \delta 145.57$, 136.64, 133.41, 131.48, 127.20, 124.24, 117.34, 62.28. HRMS (ESI): $m / z$ calcd. for $\mathrm{C}_{9} \mathrm{H}_{8} \mathrm{~N}_{3} \mathrm{O}_{4}[\mathrm{M}+\mathrm{H}]^{+}$: 194.0560; found, 194.0565.

\subsubsection{Methyl 4-Nitro-1H-Benzo[d]imidazole-6-Carboxylate (7)}

To a mixture of $100 \mathrm{mg}$ of $5 \mathrm{in} 10 \mathrm{~mL}$ of methanol was added 3 drops of concentrated sulfuric acid, and the reaction was refluxed for $2 \mathrm{~h}$ until TLC indicated the reaction to be completed. A solution of $20 \mathrm{~mL}$ of saturated sodium bicarbonate was added to the concentrated reaction mixture, which was extracted with $30 \mathrm{~mL}$ of ethyl acetate. The title compound 7 was separated by silica gel chromatography to afford $97 \mathrm{mg}$ (92\% yield). ${ }^{1} \mathrm{H}$ NMR $\left(300 \mathrm{MHz}, \mathrm{DMSO}-d_{6}\right) \delta 8.58(\mathrm{~d}, J=15.1 \mathrm{~Hz}, 3 \mathrm{H}), 3.93(\mathrm{~s}, 3 \mathrm{H})$. ${ }^{13} \mathrm{C}$ NMR (75 MHz, DMSO- $d_{6}$ ) $\delta$ 165.20, 147.55, 145.51, 133.53, 131.11, 126.61, 122.94, 119.45, 52.75. HRMS (ESI): $\mathrm{m} / z$ calcd. for $\mathrm{C}_{9} \mathrm{H}_{8} \mathrm{~N}_{3} \mathrm{O}_{4}[\mathrm{M}+\mathrm{H}]^{+}:$222.0509; found, 222.0513 .

\subsection{7. (4-Chloro-3,5-Dinitrophenyl)-Methanol (8)}

To a solution of compound $2(3 \mathrm{~g}, 12.2 \mathrm{mmol})$ in dry THF $(30 \mathrm{~mL})$ at ambient temperature and under a nitrogen atmosphere was added boron trifluoride diethyl etherate $(12 \mathrm{~mL})$, followed by the addition of borane tetrahydrofuran complex (1.0 M solution in THF, $24 \mathrm{~mL})$ over $5 \mathrm{~min}$. The mixture was stirred at ambient temperature overnight, and the reaction was quenched by carefully adding $10 \mathrm{~mL}$ of methanol until the gas evolution ceased, followed by $20 \mathrm{~mL}$ of water. The mixture was concentrated, the residue was extracted with ethyl acetate $(3 \times 30 \mathrm{~mL})$, and the combined organic extracts were washed with brine. The title compound 8 was separated with silica gel, affording $2.48 \mathrm{~g}$ (87\%). ${ }^{1} \mathrm{H}$ NMR $\left(300 \mathrm{MHz}, \mathrm{DMSO}-d_{6}\right) \delta 8.31(\mathrm{~d}, J=0.9 \mathrm{~Hz}, 2 \mathrm{H}), 4.65(\mathrm{~s}, 2 \mathrm{H}) .{ }^{13} \mathrm{C}$ NMR $(75 \mathrm{MHz}$, DMSO- $d_{6}$ ) $\delta 148.75,145.89,128.71,125.89$ (two carbons), 116.11, 60.96. HRMS (ESI): $m / z$ calcd. for $\mathrm{C}_{7} \mathrm{H}_{6} \mathrm{ClN}_{2} \mathrm{O}_{5}[\mathrm{M}+\mathrm{H}]^{+}$: 232.9960; found, 232.9959 .

\subsection{8. (4-Amino-3,5-Dinitrophenyl)-Methanol (9)}

Compound 8 (2.3 g, $9.95 \mathrm{mmol})$ was dissolved in methanol $(100 \mathrm{~mL})$, and aqueous $\mathrm{NH}_{3}(20 \mathrm{~mL})$ was gradually added. The reaction mixture was stirred at $\mathrm{rt}$ for $2.5 \mathrm{~h}$, refluxed for $3 \mathrm{~h}$ and left at ambient temperature overnight. Following concentration, the reaction mixture was subjected to a silica gel 
column, affording $1.8 \mathrm{~g}(92 \%)$ of the title compound 9. ${ }^{1} \mathrm{H}$ NMR (300 MHz, DMSO- $\left.d_{6}\right) \delta 8.43(\mathrm{~s}, 2 \mathrm{H})$, $8.35(\mathrm{~s}, 2 \mathrm{H}), 5.49(\mathrm{t}, J=5.8 \mathrm{~Hz}, 1 \mathrm{H}), 4.48(\mathrm{~d}, J=5.7 \mathrm{~Hz}, 2 \mathrm{H}) .{ }^{13} \mathrm{C}$ NMR $\left(75 \mathrm{MHz}, \mathrm{DMSO}-d_{6}\right) \delta 139.95$, $134.68,131.80$ (two carbons), $128.45,125.87,60.85$. HRMS (ESI): $m / z$ calcd. for $\mathrm{C}_{7} \mathrm{H}_{6} \mathrm{~N}_{3} \mathrm{O}_{5}[\mathrm{M}-\mathrm{H}]^{-}$: 212.0313; found, 212.0316 .

\subsection{9. (3,4-Diamino-5-Nitrophenyl)-Methanol (10)}

A suspension of $9(2.1 \mathrm{~g}, 9.85 \mathrm{mmol})$ in $\mathrm{MeOH}(40 \mathrm{~mL})$ was heated to $60{ }^{\circ} \mathrm{C}$ with stirring for about $10 \mathrm{~min}$. To this suspension was added a solution of sodium sulfide (5.4 $\mathrm{g}$ of the nonahydrate, $22.14 \mathrm{mmol}$ ) and sodium bicarbonate $(3.5 \mathrm{~g}, 41.7 \mathrm{mmol})$ in $60 \mathrm{~mL}$ of water. The reaction mixture was stirred at $70-75^{\circ} \mathrm{C}$ for $3 \mathrm{~h}$. The reaction was concentrated and subjected to silica gel chromatography, giving $1.34 \mathrm{~g}(76 \%)$ of the title compound 10. ${ }^{1} \mathrm{H}$ NMR $\left(300 \mathrm{MHz}, \mathrm{DMSO}-\mathrm{d}_{6}\right) \delta 7.29(\mathrm{~d}, J=1.7 \mathrm{~Hz}$, $1 \mathrm{H}), 6.91(\mathrm{~s}, 2 \mathrm{H}), 6.77(\mathrm{~d}, J=1.8 \mathrm{~Hz}, 1 \mathrm{H}), 5.24(\mathrm{~s}, 2 \mathrm{H}), 5.07(\mathrm{t}, J=5.7 \mathrm{~Hz}, 1 \mathrm{H}), 4.30(\mathrm{~d}, J=5.6 \mathrm{~Hz}, 2 \mathrm{H})$. ${ }^{13} \mathrm{C}$ NMR $\left(75 \mathrm{MHz}\right.$, DMSO- $d_{6}$ ) $\delta 137.74,134.60,130.67,130.09,116.41,110.56,62.52$. HRMS (ESI): $\mathrm{m} / \mathrm{z}$ calcd. for $\mathrm{C}_{7} \mathrm{H}_{8} \mathrm{~N}_{3} \mathrm{O}_{3}[\mathrm{M}-\mathrm{H}]^{-}$: 182.0571; found, 182.0571 .

\subsubsection{0. (4-Nitro-1H-Benzo[d]imidazol-6-yl)-Methyl Formate (11)}

A suspension of $10(100 \mathrm{mg}, 0.55 \mathrm{mmol})$ in $10 \mathrm{~mL}$ of formic acid was heated to $115^{\circ} \mathrm{C}$ for $3 \mathrm{~h}$, after which the reaction was concentrated, followed by adding $10 \mathrm{~mL}$ of ethyl acetate and $1 \mathrm{~mL}$ of triethylamine (TEA). The title compound was purified by silica gel column chromatography, and $70 \mathrm{mg}$ of white compound 11 was collected with a yield of $58 \% .{ }^{1} \mathrm{H}$ NMR $\left(300 \mathrm{MHz}, \mathrm{DMSO}-d_{6}\right) \delta 13.36(\mathrm{~s}, 1 \mathrm{H})$, $8.49(\mathrm{~s}, 1 \mathrm{H}), 8.36(\mathrm{~s}, 1 \mathrm{H}), 8.20(\mathrm{~d}, J=5.0 \mathrm{~Hz}, 2 \mathrm{H}), 5.38(\mathrm{~s}, 2 \mathrm{H}) .{ }^{13} \mathrm{C}$ NMR $\left(75 \mathrm{MHz}, \mathrm{DMSO}-d_{6}\right) \delta 162.06$, 146.13, 129.42, 119.21, 64.46. HRMS (ESI): $\mathrm{m} / z$ calcd. for $\mathrm{C}_{9} \mathrm{H}_{8} \mathrm{~N}_{3} \mathrm{O}_{4}[\mathrm{M}+\mathrm{H}]^{+}:$222.0509; found, 222.0513 .

5.1.11. (2R,3R,4R,5R)-2-(Acetoxymethyl)-5-((4-Nitro-1H-Benzo[d]imidazol-6-yl)methoxy) tetrahydrofuran-3,4-Diyl Diacetate (12)

Compound 6 (110 mg, $0.57 \mathrm{mmol}$ ) and 1,2,3,5-tetra-O-acetyl- $\beta$-D-ribofuranose ( $280 \mathrm{mg}, 0.63 \mathrm{mmol})$ were dissolved in $15 \mathrm{~mL}$ of dry acetonitrile, followed by adding a solution of stannic chloride $(1 \mathrm{M}$ in $\mathrm{DCM}, 3 \mathrm{~mL}$ ) into the reaction mixture. After stirring at $25^{\circ} \mathrm{C}$ for $16 \mathrm{~h}$, the reaction mixture was diluted with DCM and then poured under stirring into $60 \mathrm{~mL}$ of ice-cooled saturated sodium bicarbonate. The resulting suspension was filtered through celite, and the layers were separated. The organic layer was further washed with brine and was dried over $\mathrm{Na}_{2} \mathrm{SO}_{4}$, filtered off and evaporated. The residue was purified by silica gel column chromatography to yield $100 \mathrm{mg}(40 \%)$ of the title compound $\mathbf{1 2}$. ${ }^{1} \mathrm{H}$ NMR $\left(300 \mathrm{MHz}\right.$, DMSO- $\left.d_{6}\right) \delta 13.32(\mathrm{~s}, 1 \mathrm{H}), 8.47(\mathrm{~s}, 1 \mathrm{H}), 8.14(\mathrm{~d}, J=4.5 \mathrm{~Hz}, 2 \mathrm{H}), 5.34-5.15(\mathrm{~m}, 3 \mathrm{H})$, $4.89(\mathrm{~d}, J=11.9 \mathrm{~Hz}, 1 \mathrm{H}), 4.74(\mathrm{~d}, J=11.8 \mathrm{~Hz}, 1 \mathrm{H}), 4.30(\mathrm{dt}, J=10.2,3.7 \mathrm{~Hz}, 2 \mathrm{H}), 4.18-3.96(\mathrm{~m}, 1 \mathrm{H})$, 2.17-1.92 (m, 9H). ${ }^{13} \mathrm{C}$ NMR $\left(75 \mathrm{MHz}\right.$, DMSO- $\left.d_{6}\right) \delta 170.18,169.70,169.53,145.92,131.14,118.74,104.32$, 78.36, 74.20, 71.11, 68.48, 63.92, 20.62, 20.48, 20.44. HRMS (ESI): $m / z$ calcd. for $\mathrm{C}_{19} \mathrm{H}_{22} \mathrm{~N}_{3} \mathrm{O}_{10}[\mathrm{M}+\mathrm{H}]^{+}$: 452.1300; found, 452.1303 .

\subsubsection{6-((Tert-Butyldimethylsilyloxy)methyl)-4-Nitro-1H-Benzo[d]imidazole (13)}

The alcohol derivative 6 ( $100 \mathrm{mg}, 0.52 \mathrm{mmol})$ and TBDMSCl $(94 \mathrm{mg}, 0.63 \mathrm{mmol})$ were dissolved in $15 \mathrm{~mL}$ of dry acetonitrile, and the reaction mixture was stirred at $25^{\circ} \mathrm{C}$ for $20 \mathrm{~h}$. After the completion of the reaction, the mixture was extracted with ethyl acetate $(\mathrm{EA})(20 \mathrm{~mL})$ directly, the organic layer was further washed with brine, and the organic layer was subjected to a silica gel column to give $117 \mathrm{mg}$ of title compound 13 with a $74 \%$ yield. ${ }^{1} \mathrm{H}$ NMR $\left(300 \mathrm{MHz}, \mathrm{DMSO}-d_{6}\right) \delta 13.26(\mathrm{~s}, 1 \mathrm{H}), 8.45(\mathrm{~d}, J=2.0 \mathrm{~Hz}$, $1 \mathrm{H}), 8.10(\mathrm{~d}, J=20.1 \mathrm{~Hz}, 2 \mathrm{H}), 4.92(\mathrm{~d}, J=2.1 \mathrm{~Hz}, 2 \mathrm{H}), 0.93(\mathrm{~d}, J=2.2 \mathrm{~Hz}, 9 \mathrm{H}), 0.12(\mathrm{~d}, J=2.4 \mathrm{~Hz}, 6 \mathrm{H})$. ${ }^{13} \mathrm{C}$ NMR $\left(75 \mathrm{MHz}\right.$, DMSO- $d_{6}$ ) $\delta 145.71,135.26,116.85,63.61,25.94,18.13,-5.12$. HRMS (ESI): $\mathrm{m} / z$ calcd. for $\mathrm{C}_{14} \mathrm{H}_{22} \mathrm{~N}_{3} \mathrm{O}_{3} \mathrm{Si}[\mathrm{M}+\mathrm{H}]^{+}$: 308.1425; found, 308.1428 .

\subsubsection{6-((Tert-Butyldiphenylsilyloxy)methyl)-4-Nitro-1H-Benzo[d]imidazole (14)}

This compound was synthesized in analogy to 13 using TBDPSCl from $100 \mathrm{mg}(0.52 \mathrm{mmol})$ of 8. Yield: $89 \% .{ }^{1} \mathrm{H}$ NMR $\left(300 \mathrm{MHz}, \mathrm{DMSO}-d_{6}\right) \delta 8.46(\mathrm{~s}, 1 \mathrm{H}), 8.18(\mathrm{~s}, 1 \mathrm{H}), 8.10(\mathrm{~s}, 1 \mathrm{H}), 7.66(\mathrm{dt}, J=6.1$, 
$1.7 \mathrm{~Hz}, 4 \mathrm{H}), 7.57-7.34(\mathrm{~m}, 7 \mathrm{H}), 4.99(\mathrm{~d}, J=1.8 \mathrm{~Hz}, 2 \mathrm{H}) .{ }^{13} \mathrm{C}$ NMR $\left(75 \mathrm{MHz}, \mathrm{DMSO}-d_{6}\right) \delta 146.38,145.72$, $135.15,134.52,132.82,130.15,128.13,124.47,116.89,64.48,26.80,19.01$. HRMS (ESI): $m / z$ calcd. for $\mathrm{C}_{24} \mathrm{H}_{26} \mathrm{~N}_{3} \mathrm{O}_{3} \mathrm{Si}[\mathrm{M}+\mathrm{H}]^{+}$: 432.1739; found, 432.1740 .

5.1.14. (2R,3R,4R,5R)-2-(Acetoxymethyl)-5-((1-((2R,3R,4R,5R)-3,4-Diacetoxy-5-(Acetoxymethyl) tetrahydrofuran-2-yl)-4-Nitro-1H-Benzo[d]imidazol-6-yl)methoxy)tetrahydrofuran-3,4-Diyl Diacetate (15)

The double sugar-containing compound was obtained using the procedure for $\mathbf{1 2}$ by changing the reaction temperature to $60^{\circ} \mathrm{C}$. However, compound 12 remained the major product in this reaction, no matter whether we started from the protected compound $\mathbf{1 3}$ or $\mathbf{1 4}$. The ratio for compounds $\mathbf{1 2}$ and 15 was $3: 1$, with an overall yield of $40 \% .{ }^{13} \mathrm{C}$ NMR $\left(75 \mathrm{MHz}\right.$, DMSO- $\left.d_{6}\right) \delta 170.19,169.68,169.62$, 169.52, 169.40, 146.09, 138.70, 136.45, 135.39, 132.96, 119.09, 117.32, 104.30, 86.55, 79.92, 78.41, 74.18, 72.40, 71.10, 69.67, 68.33, 63.90, 63.00, 20.62, 20.56, 20.51, 20.46, 20.42, 20.29. HRMS (ESI): $\mathrm{m} / \mathrm{z}$ calcd. for $\mathrm{C}_{30} \mathrm{H}_{36} \mathrm{~N}_{3} \mathrm{O}_{17}[\mathrm{M}+\mathrm{H}]^{+}:$710.2039; found, 710.2040.

\subsubsection{Tert-Butyl(4-chloro-3,5-Dinitrobenzyloxy)dimethylsilane (16)}

This compound was synthesized in analogy to $\mathbf{1 3}$ (which was synthesized from 6) starting from $500 \mathrm{mg}(2.59 \mathrm{mmol})$ of 8. Yield: $84 \% .{ }^{1} \mathrm{H} \mathrm{NMR}\left(300 \mathrm{MHz}, \mathrm{CDCl}_{3}\right) \delta 8.57(\mathrm{~d}, J=1.0 \mathrm{~Hz}, 2 \mathrm{H})$, $5.44(\mathrm{t}, J=1.0 \mathrm{~Hz}, 2 \mathrm{H}), 1.58(\mathrm{~s}, 9 \mathrm{H}), 0.77(\mathrm{~s}, 6 \mathrm{H}) .{ }^{13} \mathrm{C} \mathrm{NMR}\left(75 \mathrm{MHz}, \mathrm{CDCl}_{3}\right) \delta 149.76,144.05,124.99$, 120.66, 118.50, 63.19, 62.94, 26.08, 18.59, -5.11. HRMS (ESI): $\mathrm{m} / z$ calcd. for $\mathrm{C}_{13} \mathrm{H}_{18} \mathrm{ClN}_{2} \mathrm{O}_{5} \mathrm{Si}[\mathrm{M}-\mathrm{H}]^{-}$: 345.0679; found, 345.0674 .

\subsubsection{4-((Tert-Butyldimethylsilyloxy)methyl)-2,6-Dinitroaniline (17)}

This compound was synthesized from $16(640 \mathrm{mg} 1.85 \mathrm{mmol})$ in analogy to 9 . Yield: $99 \% .{ }^{1} \mathrm{H}$ NMR $\left(300 \mathrm{MHz}, \mathrm{DMSO}-d_{6}\right) \delta 8.45(\mathrm{~s}, 1 \mathrm{H}), 8.37(\mathrm{~s}, 1 \mathrm{H}), 7.33(\mathrm{~s}, 2 \mathrm{H}), 3.35(\mathrm{~s}, 2 \mathrm{H}), 0.92(\mathrm{~s}, 5 \mathrm{H}), 0.10(\mathrm{~s}, 3 \mathrm{H})$. ${ }^{13} \mathrm{C}$ NMR $\left(75 \mathrm{MHz}\right.$, DMSO- $d_{6}$ ) $\delta 140.08,134.79,131.32,127.05,62.21,25.88,18.06,-5.18$. HRMS (ESI): $\mathrm{m} / \mathrm{z}$ calcd. for $\mathrm{C}_{13} \mathrm{H}_{20} \mathrm{~N}_{3} \mathrm{O}_{5} \mathrm{Si}[\mathrm{M}-\mathrm{H}]^{-}$: 326.1178; found, 326.1185 .

\subsubsection{5-((Tert-Butyldimethylsilyloxy)methyl)-3-Nitrobenzene-1,2-Diamine (18)}

This compound was synthesized in analogy to 10 starting from $600 \mathrm{mg}(1.83 \mathrm{mmol})$ of $\mathbf{1 7}$. Yield: $80 \% .{ }^{1} \mathrm{H}$ NMR $\left(300 \mathrm{MHz}, \mathrm{DMSO}-d_{6}\right) \delta 7.28(\mathrm{~d}, J=1.8 \mathrm{~Hz}, 1 \mathrm{H}), 6.94(\mathrm{~s}, 2 \mathrm{H}), 6.74(\mathrm{~d}, J=1.9 \mathrm{~Hz}, 1 \mathrm{H})$, $5.28(\mathrm{~s}, 2 \mathrm{H}), 4.50(\mathrm{~s}, 2 \mathrm{H}), 0.89(\mathrm{~s}, 9 \mathrm{H}), 0.07(\mathrm{~s}, 6 \mathrm{H}) .{ }^{13} \mathrm{C}$ NMR $\left(75 \mathrm{MHz}, \mathrm{DMSO}-d_{6}\right) \delta 137.91,134.76,130.57$, 128.64, 115.80, 110.35, 64.04, 25.98, 18.15, -5.06. HRMS (ESI): $m / z$ calcd. for $\mathrm{C}_{13} \mathrm{H}_{24} \mathrm{~N}_{3} \mathrm{O}_{3} \mathrm{Si}[\mathrm{M}+\mathrm{H}]^{+}$: 298.1581; found, 298.1571.

\subsubsection{6-((Tert-Butyldimethylsilyloxy)methyl)-4-Nitro-1H-Benzo[d]imidazole (13)}

Alternative procedure: A mixture of $\mathbf{1 8}(410 \mathrm{mg}, 1.38 \mathrm{mmol})$ and triethyl orthoformate $(25 \mathrm{~mL})$ was refluxed for about $3 \mathrm{~h}$ at $145^{\circ} \mathrm{C}$. After the completion of the reaction as monitored by TLC, $1.5 \mathrm{~mL}$ of formic acid was added, and the mixture was refluxed at the same temperature for another $2 \mathrm{~h}$. The solution was evaporated to dryness at reduced pressure, and the residue was dissolved in methanol and stirred at rt, overnight, in the presence of charcoal. Following the removal of the charcoal by vacuum filtration through celite-545, the filtrate was evaporated to give $300 \mathrm{mg}$ of title compound 13 as an off-white solid with a $85 \%$ yield without further purification [31]. ${ }^{1} \mathrm{H}$ NMR (300 MHz, DMSO- $d_{6}$ ) $\delta 13.28(\mathrm{~s}, 1 \mathrm{H}), 8.45(\mathrm{~s}, 1 \mathrm{H}), 8.11(\mathrm{~d}, J=19.8 \mathrm{~Hz}, 2 \mathrm{H}), 4.92(\mathrm{~s}, 2 \mathrm{H}), 0.93(\mathrm{~s}, 9 \mathrm{H}), 0.12(\mathrm{~s}, 6 \mathrm{H}) .{ }^{13} \mathrm{C}$ NMR (75 MHz, DMSO- $d_{6}$ ) $\delta 146.40,145.70,135.20,133.00,126.52,124.53,116.90,63.60,25.93,18.13,-5.12$. HRMS (ESI): $m / z$ calcd. for $\mathrm{C}_{14} \mathrm{H}_{22} \mathrm{~N}_{3} \mathrm{O}_{3} \mathrm{Si}[\mathrm{M}+\mathrm{H}]^{+}$: 308.1425; found, 308.1415.

5.1.19. (2R,3S,4S,5R)-2-(Acetoxymethyl)-5-(5-(((Tert-Butyldimethylsilyl)oxy)methyl)-7-Nitro-1HBenzo[d]imidazol-1-yl)tetrahydrofuran-3,4-Diyl Diacetate (19)

To a solution of compound $13(280 \mathrm{mg}, 0.9 \mathrm{mmol})$ in dry 1,2-dichlorethane, an amount of Bis(trimethylsilyl)acetamide (BSA) $(366 \mathrm{mg}, 1.8 \mathrm{mmol}$ ) was added, and the reaction was stirred at 
$60{ }^{\circ} \mathrm{C}$ for $40 \mathrm{~min}$. Hereafter, 1,2,3,5-tetra-O-acetyl-D-ribofuranose $(561 \mathrm{mg}, 1.8 \mathrm{mM}$, dissolved in $8 \mathrm{~mL}$ of dry 1,2-dichlorethane), TMSOTf (300 mg, $1.35 \mathrm{mmol}$ ) and $\mathrm{N}$-methylmorpholine (127 mg, $1.08 \mathrm{mmol}$ ) were added, and the reaction mixture was stirred at $65^{\circ} \mathrm{C}$ for another $2.5 \mathrm{~h}$. After completion, the reaction mixture was concentrated and portioned between $\mathrm{EA}$ and saturated $\mathrm{NaHCO}_{3}$. The residue was subjected to silica gel chromatography, and the title compound 19 was obtained with $330 \mathrm{mg}$ (64\% yield) [30]. 1H NMR (300 MHz, DMSO- $\left.d_{6}\right) \delta 8.78(\mathrm{~s}, 1 \mathrm{H}), 8.05(\mathrm{dd}, J=1.6,0.7 \mathrm{~Hz}, 1 \mathrm{H}), 7.99$ $(\mathrm{d}, J=1.4 \mathrm{~Hz}, 1 \mathrm{H}), 6.46(\mathrm{~d}, J=3.5 \mathrm{~Hz}, 1 \mathrm{H}), 5.78(\mathrm{dd}, J=5.6,3.6 \mathrm{~Hz}, 1 \mathrm{H}), 5.41(\mathrm{t}, J=6.0 \mathrm{~Hz}, 1 \mathrm{H}), 4.97-4.85$ $(\mathrm{m}, 2 \mathrm{H}), 4.40(\mathrm{ddd}, J=6.8,4.6,3.1 \mathrm{~Hz}, 1 \mathrm{H}), 4.34-4.14(\mathrm{~m}, 2 \mathrm{H}), 2.12(\mathrm{~d}, J=0.6 \mathrm{~Hz}, 3 \mathrm{H}), 2.11-2.05(\mathrm{~m}, 3 \mathrm{H})$, $1.91(\mathrm{~d}, J=0.6 \mathrm{~Hz}, 3 \mathrm{H}), 0.92(\mathrm{~d}, J=0.6 \mathrm{~Hz}, 9 \mathrm{H}), 0.11(\mathrm{~d}, J=0.6 \mathrm{~Hz}, 6 \mathrm{H}) .{ }^{13} \mathrm{C}$ NMR $\left(75 \mathrm{MHz}, \mathrm{DMSO}-d_{6}\right)$ o 169.89, 169.44, 169.23, 147.29, 144.56, 136.30, 136.14, 123.73, 118.85, 88.50, 79.13, 73.83, 69.31, 63.25, $62.49,20.40,20.33,20.30,18.09,-5.21$. HRMS (ESI): $m / z$ calcd. for $\mathrm{C}_{25} \mathrm{H}_{36} \mathrm{~N}_{3} \mathrm{O}_{10} \mathrm{Si}[\mathrm{M}+\mathrm{H}]+:$ 566.2164; found, 566.2168 .

5.1.20. (2R,3S,4S,5R)-2-(Hydroxymethyl)-5-(5-(((Tert-Butyldimethylsilyl)oxy)methyl)-7-Nitro-1HBenzo[d]imidazol-1-yl)tetrahydrofuran-3,4-Diol (20)

A solution of compound $19(327 \mathrm{mg}, 0.58 \mathrm{mmol})$ in methanolic ammonia $(7 \mathrm{~N}, 15 \mathrm{~mL})$ was stirred at $0{ }^{\circ} \mathrm{C}$ for $4 \mathrm{~h}$. The reaction was concentrated in the presence of silica gel, and the title compound 20 was purified by silica gel chromatography using EA/methanol (8:2) to afford $254 \mathrm{mg}$ (90\% yield). ${ }^{1} \mathrm{H}$ NMR $\left(300 \mathrm{MHz}, \mathrm{DMSO}-d_{6}\right) \delta 8.69(\mathrm{~s}, 1 \mathrm{H}), 8.02(\mathrm{~d}, J=1.4 \mathrm{~Hz}, 1 \mathrm{H}), 7.91(\mathrm{~d}, J=1.4 \mathrm{~Hz}, 1 \mathrm{H}), 6.05(\mathrm{~d}, J=3.9 \mathrm{~Hz}$, $1 \mathrm{H}), 5.70(\mathrm{~d}, J=5.8 \mathrm{~Hz}, 1 \mathrm{H}), 5.41(\mathrm{~d}, J=5.6 \mathrm{~Hz}, 1 \mathrm{H}), 4.90(\mathrm{~s}, 2 \mathrm{H}), 4.56(\mathrm{q}, J=4.8 \mathrm{~Hz}, 1 \mathrm{H}), 4.18-3.92$ $(\mathrm{m}, 5 \mathrm{H}), 0.93(\mathrm{~s}, 9 \mathrm{H}), 0.12(\mathrm{~s}, 6 \mathrm{H}) .{ }^{13} \mathrm{C}$ NMR $\left(75 \mathrm{MHz}, \mathrm{DMSO}-d_{6}\right) \delta 147.17,144.44,136.49,135.95,123.91$, $123.12,118.36,89.75,81.59,73.83,70.09,63.33,63.12,25.92,18.12,-5.14$. HRMS (ESI): $m / z$ calcd. for $\mathrm{C}_{21} \mathrm{H}_{32} \mathrm{~N}_{3} \mathrm{O}_{8} \mathrm{Si}[\mathrm{M}+\mathrm{H}]^{+}$: 482.1953; found, 482.1962 .

5.1.21. (1-(2. R,3S,4S,5R)-(6-(Hydroxymethyl)-2,2-Dimethyltetrahydrofuro[3,4-d][1,3]dioxol-4-yl)-7Nitro-1H-Benzo[d]imidazol-5-yl)methanol (21)

To a solution of compound 20 (1.66 g, $3.77 \mathrm{mmol})$, suspended in dry acetone $(500 \mathrm{~mL})$, was added $37 \mathrm{mM}$ dry $p$-toluenesulfonic acid (6.5 g, $10 \mathrm{eq}$.) in one portion. The mixture was stirred under a nitrogen atmosphere and turned into a yellow solution upon dissolution. After $3 \mathrm{~h}$, a saturated $\mathrm{NaHCO}_{3}$ solution $(500 \mathrm{~mL})$ cooled to $0{ }^{\circ} \mathrm{C}$ was added with stirring over $5 \mathrm{~min}$. The solvents were removed under reduced pressure, and the residue was portioned between ethyl acetate $(200 \mathrm{~mL})$ and water [32]. The solvent was evaporated, and the title compound 21 was purified by silica gel chromatography (EA/MeOH 9:1) with an 81\% yield (1.08 g, $2.95 \mathrm{mM}) .{ }^{1} \mathrm{H}$ NMR (300 MHz, DMSO- $\left.d_{6}\right) \delta 8.76(\mathrm{~s}, 1 \mathrm{H})$, $8.00(\mathrm{~d}, J=1.4 \mathrm{~Hz}, 1 \mathrm{H}), 7.90(\mathrm{~d}, J=1.4 \mathrm{~Hz}, 1 \mathrm{H}), 6.26(\mathrm{~d}, J=1.8 \mathrm{~Hz}, 1 \mathrm{H}), 5.38(\mathrm{dd}, J=5.9,2.0 \mathrm{~Hz}, 1 \mathrm{H})$, $4.83(\mathrm{dd}, J=5.9,2.2 \mathrm{~Hz}, 1 \mathrm{H}), 4.66(\mathrm{~s}, 2 \mathrm{H}), 4.09(\mathrm{ddd}, J=6.2,4.2,2.1 \mathrm{~Hz}, 1 \mathrm{H}), 3.08(\mathrm{dd}, J=11.6,4.3 \mathrm{~Hz}$, 1H), $2.88(\mathrm{dd}, J=11.6,5.9 \mathrm{~Hz}, 1 \mathrm{H}), 1.49(\mathrm{~s}, 3 \mathrm{H}), 1.32(\mathrm{~s}, 3 \mathrm{H}) .{ }^{13} \mathrm{C}$ NMR $\left(75 \mathrm{MHz}, \mathrm{DMSO}-d_{6}\right) \delta$ 147.20, $144.82,137.44,136.55,123.62,123.41,118.83,112.64,91.20,86.81,83.34,81.11,62.00,60.72,26.79,25.19$. HRMS (ESI): $m / z$ calcd. for $\mathrm{C}_{16} \mathrm{H}_{20} \mathrm{~N}_{3} \mathrm{O}_{7}[\mathrm{M}+\mathrm{H}]^{+}:$366.1296; found, 366.1299.

\subsubsection{5-(Benzyloxy)methyl-2-Chloro-1,3-Dinitrobenzene (22)}

To a solution of compound 8 (500 mg, $2.59 \mathrm{mmol})$ in $20 \mathrm{~mL}$ of 1,4-dioxane was added benzyl 2,2,2-trichloroacetimidate $(1.3 \mathrm{~g}, 5.2 \mathrm{mmol})$ and trifluoromethanesulfonic acid (200 $\mathrm{mg}, 1.3 \mathrm{mmol})$, and the reaction mixture was stirred at $\mathrm{rt}$ for $1 \mathrm{~h}$. The reaction was portioned between EA and saturated $\mathrm{NaHCO}_{3}$; the organic layer was concentrated and subjected to a silica gel column. The title compound 22 was separated with a 95\% yield $(680 \mathrm{mg}) .{ }^{1} \mathrm{H}$ NMR $\left(300 \mathrm{MHz}, \mathrm{CDCl}_{3}\right) \delta 8.59(\mathrm{~d}, J=0.9 \mathrm{~Hz}, 2 \mathrm{H})$, 8.11-7.91 (m, 5H), $5.29(\mathrm{~s}, 2 \mathrm{H}), 5.25(\mathrm{~d}, J=0.9 \mathrm{~Hz}, 2 \mathrm{H}) .{ }^{13} \mathrm{C} \mathrm{NMR}\left(75 \mathrm{MHz}, \mathrm{CDCl}_{3}\right) \delta 141.13,136.99$, $129.29,129.00,128.64,128.46,128.24,128.04,126.14,119.09,73.70,69.25$. HRMS (ESI): $\mathrm{m} / \mathrm{z}$ calcd. for $\mathrm{C}_{14} \mathrm{H}_{12} \mathrm{ClN}_{2} \mathrm{O}_{5}[\mathrm{M}+\mathrm{H}]^{+}$: 323.0429; found, 323.0424. 


\subsubsection{4-(Benzyloxy)methyl-2,6-Dinitroaniline (23)}

This compound was synthesized in analogy to 9 starting from $680 \mathrm{mg}(2.11 \mathrm{mmol})$ of 22. Yield: $96 \%$. ${ }^{1} \mathrm{H}$ NMR $\left(300 \mathrm{MHz}\right.$, DMSO- $\left.d_{6}\right) \delta 8.48(\mathrm{~s}, 2 \mathrm{H}), 8.40(\mathrm{~s}, 2 \mathrm{H}), 7.40-7.31(\mathrm{~m}, 5 \mathrm{H}), 4.57(\mathrm{~s}, 2 \mathrm{H}), 4.54(\mathrm{~s}, 2 \mathrm{H})$. ${ }^{13} \mathrm{C}$ NMR $\left(75 \mathrm{MHz}\right.$, DMSO- $\left.d_{6}\right) \delta 140.33,134.84,132.99,128.54,128.45,127.80,127.71,127.26,127.16$, 124.22, 71.75, 69.32. HRMS (ESI): $m / z$ calcd. for $\mathrm{C}_{14} \mathrm{H}_{14} \mathrm{~N}_{3} \mathrm{O}_{5}[\mathrm{M}+\mathrm{H}]^{+}: 304.0928$; found, 304.0930 .

\subsubsection{5-(Benzyloxy)methyl-3-Nitrobenzene-1,2-Diamine (24)}

This compound was synthesized in analogy to 10 starting from $630 \mathrm{mg}(2.08 \mathrm{mmol})$ of 23 . Yield: 80\%. ${ }^{1} \mathrm{H}$ NMR (300 MHz, DMSO- $\left.d_{6}\right) \delta=7.50-7.16(\mathrm{~m}, 6 \mathrm{H}), 7.01(\mathrm{~s}, 2 \mathrm{H}), 6.81(\mathrm{~d}, J=1.8,1 \mathrm{H}), 5.34$ $(\mathrm{s}, 2 \mathrm{H}), 4.47(\mathrm{~s}, 2 \mathrm{H}), 4.34(\mathrm{~s}, 2 \mathrm{H})$. HRMS (ESI): $\mathrm{m} / z$ calcd. for $\mathrm{C}_{14} \mathrm{H}_{16} \mathrm{~N}_{3} \mathrm{O}_{3}[\mathrm{M}+\mathrm{H}]^{+}:$:274.1186; found, 274.1188.

\subsubsection{6-(Benzyloxy)methyl-4-Nitro-1H-benzo[d]imidazole (25)}

This compound was synthesized in analogy to 13 (which was synthesized from 18) starting from $550 \mathrm{mg}(2.0 \mathrm{mmol})$ of 24 . Yield: $84 \% .{ }^{1} \mathrm{H}$ NMR $\left(300 \mathrm{MHz}, \mathrm{DMSO}-d_{6}\right) \delta 13.31(\mathrm{~s}, 1 \mathrm{H}), 8.47(\mathrm{~s}, 1 \mathrm{H}), 8.16$ (s, 2H), 7.53-7.09 (m, 5H), $4.75(\mathrm{~s}, 2 \mathrm{H}), 4.60(\mathrm{~s}, 2 \mathrm{H}) .{ }^{13} \mathrm{C}$ NMR $\left(75 \mathrm{MHz}\right.$, DMSO- $\left.d_{6}\right) \delta 145.81,138.35$, $132.31,128.45,127.72,127.66,126.23,118.39,71.69,70.76$. HRMS (ESI): $m / z$ calcd. For $\mathrm{C}_{15} \mathrm{H}_{14} \mathrm{~N}_{3} \mathrm{O}_{3}$ $[\mathrm{M}+\mathrm{H}]^{+}:$284.1030; found, 284.1021 .

5.1.26. (2R,3S,4S,5R)-2-(Acetoxymethyl)-5-(5-((Benzyloxy)methyl)-7-Nitro-1H-Benzo[d]imidazol1-yl)tetrahydrofuran-3,4-Diyl Diacetate (26)

This compound was synthesized in analogy to 19 starting from $1.44 \mathrm{~g}(5.09 \mathrm{mmol})$ of 25 . Yield: 64\%. ${ }^{1} \mathrm{H}$ NMR $\left(300 \mathrm{MHz}, \mathrm{DMSO}-d_{6}\right) \delta 8.80(\mathrm{~s}, 1 \mathrm{H}), 8.13(\mathrm{~d}, J=1.4 \mathrm{~Hz}, 1 \mathrm{H}), 8.03(\mathrm{~d}, J=1.4 \mathrm{~Hz}, 1 \mathrm{H})$, $7.50-7.22(\mathrm{~m}, 5 \mathrm{H}), 6.46(\mathrm{~d}, J=3.6 \mathrm{~Hz}, 1 \mathrm{H}), 5.79(\mathrm{dd}, J=5.6,3.6 \mathrm{~Hz}, 1 \mathrm{H}), 5.40(\mathrm{t}, J=6.0 \mathrm{~Hz}, 1 \mathrm{H}), 4.74$ $(\mathrm{s}, 2 \mathrm{H}), 4.60(\mathrm{~s}, 2 \mathrm{H}), 4.40(\mathrm{dq}, J=6.4,3.1 \mathrm{~Hz}, 1 \mathrm{H}), 4.34-4.15(\mathrm{~m}, 2 \mathrm{H}), 2.12(\mathrm{~s}, 3 \mathrm{H}), 2.08(\mathrm{~s}, 3 \mathrm{H}), 1.91(\mathrm{~s}, 3 \mathrm{H})$. ${ }^{13} \mathrm{C}$ NMR $\left(75 \mathrm{MHz}\right.$, DMSO- $\left.d_{6}\right) \delta 169.93,169.46,169.26,147.25,144.66,138.29,136.24,133.42,128.45$, $127.71,127.67,125.42,124.06,120.28,88.52,79.14,73.81,71.75,70.33,69.32,62.49,20.43,20.37,20.33$. HRMS (ESI): $m / z$ calcd. For $\mathrm{C}_{26} \mathrm{H}_{27} \mathrm{~N}_{3} \mathrm{O}_{10} \mathrm{Na}[\mathrm{M}+\mathrm{Na}]^{+}$: 564.1589; found, 564.1607.

5.1.27. (2R,3S,4S,5R)-2-(5-((Benzyloxy)methyl)-7-Nitro-1H-Benzo[d]imidazol-1-yl)-5(Hydroxymethyl)tetrahydrofuran-3,4-Diol (27)

This compound was synthesized in analogy to 20 starting from $1.55 \mathrm{~g}(2.86 \mathrm{mmol})$ of 26 . Yield: $66 \% .{ }^{1} \mathrm{H}$ NMR $\left(300 \mathrm{MHz}, \mathrm{DMSO}-d_{6}\right) \delta 8.86(\mathrm{~s}, 1 \mathrm{H}), 8.10(\mathrm{~d}, J=1.4 \mathrm{~Hz}, 1 \mathrm{H}), 7.98(\mathrm{~d}, J=1.4 \mathrm{~Hz}, 1 \mathrm{H})$, $7.47-7.25(\mathrm{~m}, 5 \mathrm{H}), 6.08(\mathrm{~d}, J=5.0 \mathrm{~Hz}, 1 \mathrm{H}), 5.51(\mathrm{~d}, J=6.2 \mathrm{~Hz}, 1 \mathrm{H}), 5.23(\mathrm{~d}, J=5.0 \mathrm{~Hz}, 1 \mathrm{H}), 5.03$ $(\mathrm{t}, J=5.2 \mathrm{~Hz}, 1 \mathrm{H}), 4.73(\mathrm{~s}, 2 \mathrm{H}), 4.60(\mathrm{~s}, 2 \mathrm{H}), 4.29(\mathrm{q}, J=5.3 \mathrm{~Hz}, 1 \mathrm{H}), 4.15-3.98(\mathrm{~m}, 1 \mathrm{H}), 3.95(\mathrm{~d}, J=3.8 \mathrm{~Hz}$, 1H), 3.70-3.42 (m, 2H). ${ }^{13} \mathrm{C}$ NMR (75 MHz, DMSO-d $\left.d_{6}\right) \delta 147.33,144.92,138.33,136.24,132.83,128.46$, $127.71,127.67,125.01,124.36,119.82,89.52,85.34,75.19,71.73,70.45,69.96,60.71$. HRMS (ESI): $\mathrm{m} / \mathrm{z}$ calcd. For $\mathrm{C}_{20} \mathrm{H}_{22} \mathrm{~N}_{3} \mathrm{O}_{7}[\mathrm{M}+\mathrm{H}]^{+}$: 416.1452; found, 416.1447 .

5.1.28. (2R,3S,4S,5R)-(6-(5-((Benzyloxy)methyl)-7-Nitro-1H-Benzo[d]imidazol-1-yl)-2,2Dimethyltetrahydrofuro[3,4-d][1,3]dioxol-4-yl)Methanol (28)

This compound was synthesized in analogy to 21 starting from $680 \mathrm{mg}$ (1.64 mmol) of 27. Yield: $78 \% .{ }^{1} \mathrm{H}$ NMR $\left(300 \mathrm{MHz}, \mathrm{CDCl}_{3}\right) \delta 9.27(\mathrm{~s}, 1 \mathrm{H}), 8.50(\mathrm{dd}, J=10.1,1.5 \mathrm{~Hz}, 2 \mathrm{H}), 8.11-7.85(\mathrm{~m}, 5 \mathrm{H}), 7.09$ $(\mathrm{d}, J=3.2 \mathrm{~Hz}, 1 \mathrm{H}), 5.59(\mathrm{dd}, J=6.1,2.6 \mathrm{~Hz}, 1 \mathrm{H}), 5.50(\mathrm{dd}, J=6.1,3.2 \mathrm{~Hz}, 1 \mathrm{H}), 5.23(\mathrm{~d}, J=7.5 \mathrm{~Hz}, 4 \mathrm{H})$, $5.06(\mathrm{t}, J=2.5 \mathrm{~Hz}, 1 \mathrm{H}), 4.55(\mathrm{dd}, J=12.0,2.5 \mathrm{~Hz}, 1 \mathrm{H}), 4.43(\mathrm{dd}, J=12.1,2.7 \mathrm{~Hz}, 1 \mathrm{H}), 2.27(\mathrm{~s}, 3 \mathrm{H}), 1.99$ (s, 3H). ${ }^{13} \mathrm{C} \mathrm{NMR}\left(75 \mathrm{MHz}, \mathrm{CDCl}_{3}\right) \delta 146.93,144.57,137.92,136.84,133.52,128.80,128.19,128.13,125.05$, 124.30, 120.77, 114.75, 92.94, 86.61, 85.55, 81.21, 72.91, 71.03, 62.12, 27.45, 25.73. HRMS (ESI): $\mathrm{m} / z$ calcd. For $\mathrm{C}_{23} \mathrm{H}_{26} \mathrm{~N}_{3} \mathrm{O}_{7}[\mathrm{M}+\mathrm{H}]^{+}$: 456.1765; found, 456.1759 . 
5.1.29. (2R,3S,4S,5R)-(6-(5-((Benzyloxy)methyl)-7-Nitro-1H-Benzo[d]imidazol-1-yl)-2,2Dimethyltetrahydrofuro[3,4-d][1,3]dioxol-4-yl)methyl Sulfamate (29)

Chlorosulfonyl isocyanate $(630 \mathrm{mg}, 4.5 \mathrm{mmol})$ was taken into a $10 \mathrm{~mL}$ flask, and after cooling to $0{ }^{\circ} \mathrm{C}$, formic acid $(210 \mathrm{mg}, 4.5 \mathrm{mmol})$ was added and the mixture was stirred for $5 \mathrm{~min}$. The resulting solid was dissolved in dry acetonitrile $(6 \mathrm{~mL})$, and the solution was cooled to $0{ }^{\circ} \mathrm{C}$ and stirred for another $5 \mathrm{~h}$, gradually reaching rt. Compound $28(580 \mathrm{mg}, 1.27 \mathrm{mmol})$ was dissolved in $30 \mathrm{~mL}$ of dimethylacetamide (DMA) and cooled to $0{ }^{\circ} \mathrm{C}$, followed by adding the obtained sulfamoyl chloride, and the mixture was stirred overnight. The next morning, $3 \mathrm{~mL}$ of TEA was added, and the reaction was stirred for $10 \mathrm{~min}$, followed by adding $6 \mathrm{~mL}$ of methanol and further stirring for $15 \mathrm{~min}$. The reaction was concentrated, and the residue was partitioned between EA and saturated $\mathrm{NaHCO}_{3}$. The organic layer was further washed with water and brine, and the title compound 29 was purified by silica gel chromatography with a $84 \%$ yield $(570 \mathrm{mg}) .{ }^{1} \mathrm{H}$ NMR $\left(300 \mathrm{MHz}, \mathrm{DMSO}-d_{6}\right) \delta 8.75(\mathrm{~s}, 1 \mathrm{H}), 8.19-8.07$ $(\mathrm{m}, 1 \mathrm{H}), 8.01(\mathrm{~d}, J=1.4 \mathrm{~Hz}, 1 \mathrm{H}), 7.56(\mathrm{~s}, 2 \mathrm{H}), 7.47-7.25(\mathrm{~m}, 5 \mathrm{H}), 6.39(\mathrm{~d}, J=1.9 \mathrm{~Hz}, 1 \mathrm{H}), 5.48(\mathrm{dd}, J=6.0$, $2.0 \mathrm{~Hz}, 1 \mathrm{H}), 4.94(\mathrm{dd}, J=6.0,3.0 \mathrm{~Hz}, 1 \mathrm{H}), 4.74(\mathrm{~s}, 2 \mathrm{H}), 4.60(\mathrm{~s}, 2 \mathrm{H}), 4.36(\mathrm{~m}, 1 \mathrm{H}), 3.75(\mathrm{~m}, 2 \mathrm{H}), 1.55$ $(\mathrm{s}, 3 \mathrm{H}), 1.37(\mathrm{~s}, 3 \mathrm{H}) .{ }^{13} \mathrm{C}$ NMR $\left(75 \mathrm{MHz}, \mathrm{DMSO}-d_{6}\right) \delta 147.16,144.73,138.28,136.50,133.41,128.46,127.75$, $127.69,125.12,123.80,120.12,113.45,90.92,83.36,83.32,80.50,71.76,70.37,67.44,26.83,25.27$. HRMS (ESI): $m / z$ calcd. for $\mathrm{C}_{23} \mathrm{H}_{27} \mathrm{~N}_{4} \mathrm{O}_{9} \mathrm{~S}[\mathrm{M}+\mathrm{H}]^{+}:$535.1493; found, 535.1503.

5.1.30. (2R,3S,4S,5R)-(6-(5-((Benzyloxy)methyl)-7-Nitro-1H-Benzo[d]imidazol-1-yl)-2,2Dimethyltetrahydrofuro[3,4-d][1,3]dioxol-4-yl)methyl ((Tert-Butoxycarbonyl)glycyl)sulfamate (30a)

Compound 29 (140 mg, $0.26 \mathrm{mM})$ and Boc-Gly-OSu (140 mg, $0.52 \mathrm{mmol})$ were dissolved in $16 \mathrm{~mL}$ of dry DMF, followed by adding DBU $(60 \mathrm{mg}, 0.39 \mathrm{mmol})$, and the reaction was stirred at $\mathrm{rt}$ overnight. The reaction was concentrated under vacuum, and the residue was dissolved in EA and washed with saturated $\mathrm{NaHCO}_{3}$. The title compound 30a was purified by silica gel chromatography with a 77\% yield (EA:hexane, 2:1). ${ }^{1} \mathrm{H}$ NMR $\left(300 \mathrm{MHz}, \mathrm{DMSO}-d_{6}\right) \delta 8.81(\mathrm{~s}, 1 \mathrm{H}), 8.10(\mathrm{~d}, J=1.5 \mathrm{~Hz}$, $1 \mathrm{H}), 7.98(\mathrm{~d}, J=1.4 \mathrm{~Hz}, 1 \mathrm{H}), 7.51-7.19(\mathrm{~m}, 6 \mathrm{H}), 6.33(\mathrm{~d}, J=2.1 \mathrm{~Hz}, 1 \mathrm{H}), 5.41(\mathrm{dd}, J=5.9,2.2 \mathrm{~Hz}, 1 \mathrm{H})$, $4.95(\mathrm{dd}, J=5.9,2.3 \mathrm{~Hz}, 1 \mathrm{H}), 4.74(\mathrm{~s}, 2 \mathrm{H}), 4.60(\mathrm{~d}, J=3.1 \mathrm{~Hz}, 2 \mathrm{H}), 4.31(\mathrm{~s}, 1 \mathrm{H}), 3.80-3.59(\mathrm{~m}, 1 \mathrm{H})$, $3.40(\mathrm{~d}, J=5.8 \mathrm{~Hz}, 1 \mathrm{H}), 1.53(\mathrm{~s}, 3 \mathrm{H}), 1.46-1.28(\mathrm{~m}, 12 \mathrm{H}) .{ }^{13} \mathrm{C}$ NMR $\left(75 \mathrm{MHz}, \mathrm{DMSO}-d_{6}\right) \delta 173.55$, 155.61, 147.20, 144.95, 138.31, 136.46, 133.31, 128.44, 127.74, 127.65, 125.00, 123.75, 119.92, 112.94, 91.40, 83.83, 83.41, 81.15, 77.67, 71.75, 70.39, 66.17, 45.63, 28.38, 26.86, 25.29. HRMS (ESI): $\mathrm{m} / \mathrm{z}$ calcd. for $\mathrm{C}_{30} \mathrm{H}_{36} \mathrm{~N}_{5} \mathrm{O}_{12} \mathrm{~S}[\mathrm{M}-\mathrm{H}]^{-}:$690.2086; found, 690.2086.

5.1.31. (2R,3S,4S,5R)-(6-(5-((Benzyloxy)methyl)-7-Nitro-1H-Benzo[d]imidazol-1-yl)-2,2Dimethyltetrahydrofuro[3,4-d][1,3]dioxol-4-yl)methyl (3-(4-(benzyloxy)phenyl)-2-((TertButoxycarbonyl)amino)propanoyl)sulfamate (30b)

This compound was synthesized in analogy to 30a using Boc-Tyr(OBn)-OSu, using $300 \mathrm{mg}$ (0.56 mmol) of starting compound 29. Yield: 99\%. ${ }^{1} \mathrm{H}$ NMR (300 MHz, DMSO- $\left.d_{6}\right) \delta 8.80(\mathrm{~s}, 1 \mathrm{H}), 8.07$ $(\mathrm{d}, J=1.4 \mathrm{~Hz}, 1 \mathrm{H}), 7.97(\mathrm{~d}, J=1.4 \mathrm{~Hz}, 1 \mathrm{H}), 7.50-7.23(\mathrm{~m}, 10 \mathrm{H}), 6.98(\mathrm{dd}, J=67.8,8.1 \mathrm{~Hz}, 5 \mathrm{H}), 6.35$ $(\mathrm{d}, J=2.2 \mathrm{~Hz}, 1 \mathrm{H}), 6.32-6.06(\mathrm{~m}, 1 \mathrm{H}), 5.47-5.31(\mathrm{~m}, 1 \mathrm{H}), 5.12-4.87(\mathrm{~m}, 4 \mathrm{H}), 4.70(\mathrm{~s}, 2 \mathrm{H}), 4.58(\mathrm{~s}, 2 \mathrm{H})$, $4.34(\mathrm{dt}, J=6.9,3.5 \mathrm{~Hz}, 1 \mathrm{H}), 3.76(\mathrm{~m}, 3 \mathrm{H}), 2.91(\mathrm{~d}, J=13.7 \mathrm{~Hz}, 1 \mathrm{H}), 2.69(\mathrm{dd}, J=13.6,8.5 \mathrm{~Hz}, 1 \mathrm{H}), 1.53$ $(\mathrm{s}, 3 \mathrm{H}), 1.32(\mathrm{~d}, J=10.5 \mathrm{~Hz}, 12 \mathrm{H}) .{ }^{13} \mathrm{C}$ NMR $\left(75 \mathrm{MHz}, \mathrm{DMSO}-d_{6}\right) \delta 156.89,155.01,147.22,144.93,138.30$, 137.41, 136.41, 133.29, 130.43, 128.50, 128.43, 128.40, 127.83, 127.72, 127.69, 127.64, 125.05, 123.79, 119.95, $114.30,113.12,91.32,83.59,80.95,77.78,71.73,70.37,69.27,57.55,28.32,26.89,25.29$. HRMS (ESI): $m / z$ calcd. for $\mathrm{C}_{44} \mathrm{H}_{48} \mathrm{~N}_{5} \mathrm{O}_{13} \mathrm{~S}[\mathrm{M}-\mathrm{H}]^{-}$: 886.2975; found, 886.3018.

5.1.32. (2R,3S,4S,5R)-(6-(5-((Benzyloxy)methyl)-7-Nitro-1H-Benzo[d]imidazol-1-yl)-2,2Dimethyltetrahydrofuro[3,4-d][1,3]dioxol-4-yl)methyl (O-Benzyl-N-(Tert-Butoxycarbonyl) seryl)sulfamate (30c)

This compound was synthesized in analogy to 30a using the appropriate protected serine, using $347 \mathrm{mg}$ (0.65 mmol) of starting compound 29. Yield: 95\%. ${ }^{1} \mathrm{H}$ NMR (300 MHz, DMSO- $\left.d_{6}\right) \delta 8.79$ 
(s, 1H), $8.09(\mathrm{~d}, J=1.4 \mathrm{~Hz}, 1 \mathrm{H}), 7.98(\mathrm{~d}, J=1.4 \mathrm{~Hz}, 1 \mathrm{H}), 7.45-7.18(\mathrm{~m}, 10 \mathrm{H}), 6.33(\mathrm{~d}, J=2.3 \mathrm{~Hz}, 1 \mathrm{H})$, $6.10(\mathrm{~d}, J=8.1 \mathrm{~Hz}, 1 \mathrm{H}), 5.32(\mathrm{dd}, J=6.1,2.4 \mathrm{~Hz}, 1 \mathrm{H}), 4.92(\mathrm{dd}, J=5.9,2.3 \mathrm{~Hz}, 1 \mathrm{H}), 4.72(\mathrm{~s}, 2 \mathrm{H}), 4.59$ $(\mathrm{s}, 2 \mathrm{H}), 4.42(\mathrm{~d}, J=2.1 \mathrm{~Hz}, 2 \mathrm{H}), 4.30(\mathrm{~d}, J=6.1 \mathrm{~Hz}, 1 \mathrm{H}), 3.94(\mathrm{~s}, 2 \mathrm{H}), 3.83-3.46(\mathrm{~m}, 4 \mathrm{H}), 1.52(\mathrm{~s}, 3 \mathrm{H})$, $1.35(\mathrm{~d}, J=11.5 \mathrm{~Hz}, 12 \mathrm{H}) .{ }^{13} \mathrm{C}$ NMR $\left(75 \mathrm{MHz}\right.$, DMSO- $\left.d_{6}\right) \delta 173.90,155.00,147.22,145.00,138.72,138.30$, 136.37, 133.27, 128.44, 128.18, 127.81, 127.73, 127.65, 127.48, 127.31, 125.05, 123.78, 119.94, 113.01, 91.38, 83.74, 83.61, 81.09, 77.78, 71.93, 71.73, 71.24, 70.37, 66.32, 56.62, 28.35, 26.91, 25.29. HRMS (ESI): $\mathrm{m} / \mathrm{z}$ calcd. for $\mathrm{C}_{38} \mathrm{H}_{44} \mathrm{~N}_{5} \mathrm{O}_{13} \mathrm{~S}$ [M-H] $]^{-}$: 810.2662; found, 810.2668.

5.1.33. Tert-Butyl 4-(((6-(5-((Benzyloxy)methyl)-7-Nitro-1H-Benzo[d]imidazol-1-yl)-2,2-

Dimethyltetrahydrofuro[3,4-d][1,3]dioxol-4-yl)methoxy)sulfonyl)amino)-3-((Tert-Butoxycarbonyl) amino)-4-oxobutanoate (30d)

This compound was synthesized in analogy to 30a with the aid of the appropriately protected aspartic acid, using $300 \mathrm{mg}(0.56 \mathrm{mmol})$ of starting compound 29. Yield: $99 \%$. ${ }^{1} \mathrm{H}$ NMR $(300 \mathrm{MHz}$, DMSO- $\left.d_{6}\right) \delta 8.77(\mathrm{~s}, 1 \mathrm{H}), 8.10(\mathrm{~d}, J=1.4 \mathrm{~Hz}, 1 \mathrm{H}), 7.98(\mathrm{~d}, J=1.4 \mathrm{~Hz}, 1 \mathrm{H}), 7.48-7.22(\mathrm{~m}, 5 \mathrm{H}), 6.34$ $(\mathrm{d}, J=2.3 \mathrm{~Hz}, 1 \mathrm{H}), 5.37(\mathrm{dd}, J=6.2,2.3 \mathrm{~Hz}, 1 \mathrm{H}), 4.93(\mathrm{dd}, J=5.9,2.4 \mathrm{~Hz}, 1 \mathrm{H}), 4.74(\mathrm{~s}, 2 \mathrm{H}), 4.60(\mathrm{~s}, 2 \mathrm{H})$, $4.41-4.26(\mathrm{~m}, 1 \mathrm{H}), 4.19-4.04(\mathrm{~m}, 2 \mathrm{H}), 3.78(\mathrm{dd}, J=10.9,4.3 \mathrm{~Hz}, 1 \mathrm{H}), 3.63(\mathrm{~s}, 0 \mathrm{H}), 3.18(\mathrm{~s}, 2 \mathrm{H}), 2.70-2.54$ $(\mathrm{m}, 1 \mathrm{H}), 2.35(\mathrm{dd}, J=15.3,8.4 \mathrm{~Hz}, 1 \mathrm{H}), 1.53(\mathrm{~s}, 3 \mathrm{H}), 1.46-1.27(\mathrm{~m}, 21 \mathrm{H}) .{ }^{13} \mathrm{C}$ NMR $\left(75 \mathrm{MHz}\right.$, DMSO- $\left.d_{6}\right) \delta$ 170.02, 154.96, 147.20, 144.95, 138.30, 136.40, 133.28, 128.43, 127.72, 127.65, 125.05, 123.78, 119.97, 113.08, 91.33, 83.62, 83.53, 81.00, 79.73, 77.86, 71.73, 70.37, 48.73, 29.72, 28.31, 27.81, 27.78, 26.89, 25.28. HRMS (ESI): $m / z$ calcd. for $\mathrm{C}_{36} \mathrm{H}_{46} \mathrm{~N}_{5} \mathrm{O}_{14} \mathrm{~S}[\mathrm{M}-\mathrm{H}]^{-}$: 804.2767; found, 804.2786.

5.1.34. (2R,3S,4S,5R)-(6-(5-((Benzyloxy)methyl)-7-Nitro-1H-Benzo[d]imidazol-1-yl)-2,2Dimethyltetrahydrofuro[3,4-d][1,3]dioxol-4-yl)methyl ((Tert-Butoxycarbonyl)leucyl)sulfamate (30e)

This compound was synthesized in analogy to 30a using Boc-Leu-OSu, using $220 \mathrm{mg}(0.41 \mathrm{mmol})$ of starting compound 29. Yield: 72\%. ${ }^{1} \mathrm{H}$ NMR $\left(300 \mathrm{MHz}, \mathrm{DMSO}-\mathrm{d}_{6}\right) \delta 8.80(\mathrm{~s}, 1 \mathrm{H}), 8.10(\mathrm{~d}, J=1.4 \mathrm{~Hz}$, $1 \mathrm{H}), 7.98(\mathrm{~d}, J=1.4 \mathrm{~Hz}, 1 \mathrm{H}), 7.47-7.22(\mathrm{~m}, 5 \mathrm{H}), 6.32(\mathrm{~d}, J=2.3 \mathrm{~Hz}, 1 \mathrm{H}), 6.05(\mathrm{~d}, J=8.6 \mathrm{~Hz}, 1 \mathrm{H}), 5.36$ $(\mathrm{d}, J=5.6 \mathrm{~Hz}, 1 \mathrm{H}), 4.93(\mathrm{dd}, J=6.0,2.2 \mathrm{~Hz}, 1 \mathrm{H}), 4.74(\mathrm{~s}, 2 \mathrm{H}), 4.60(\mathrm{~s}, 2 \mathrm{H}), 4.33(\mathrm{~s}, 1 \mathrm{H}), 3.82-3.63(\mathrm{~m}, 2 \mathrm{H})$, $3.51(\mathrm{dd}, J=11.0,5.7 \mathrm{~Hz}, 1 \mathrm{H}), 1.67-1.23(\mathrm{~m}, 18 \mathrm{H}), 0.83(\mathrm{dd}, J=6.5,1.5 \mathrm{~Hz}, 6 \mathrm{H}) .{ }^{13} \mathrm{C}$ NMR $(75 \mathrm{MHz}$, DMSO- $d_{6}$ ) $\delta 177.14,155.13,147.20,145.00,138.30,136.39,133.26,128.44,127.72,127.65,125.01,123.77$, 119.92, 112.97, 91.36, 83.79, 83.58, 81.16, 77.47, 71.74, 70.37, 66.21, 54.90, 42.59, 28.36, 26.91, 25.31, 24.54, 23.29, 21.99. HRMS (ESI): $\mathrm{m} / z$ calcd. for $\mathrm{C}_{34} \mathrm{H}_{44} \mathrm{~N}_{5} \mathrm{O}_{12} \mathrm{~S}[\mathrm{M}-\mathrm{H}]^{-}:$746.2712; found, 746.2708.

5.1.35. (2R,3S,4S,5R)-(6-(5-((Benzyloxy)methyl)-7-Nitro-1H-benzo[d]imidazol-1-yl)-2,2-

Dimethyltetrahydrofuro[3,4-d][1,3]dioxol-4-yl)methyl ((Tert-Butoxycarbonyl)isoleucyl)sulfamate (30f)

This compound was synthesized in analogy to 30a using Boc-Ile-OSu, using $140 \mathrm{mg}(0.26 \mathrm{mmol})$ of starting compound 29. Yield: $82 \% .{ }^{1} \mathrm{H}$ NMR $\left(300 \mathrm{MHz}, \mathrm{DMSO}-d_{6}\right) \delta 8.80(\mathrm{~s}, 1 \mathrm{H}), 8.10(\mathrm{~d}, J=1.5 \mathrm{~Hz}$, $1 \mathrm{H}), 7.98(\mathrm{~d}, J=1.4 \mathrm{~Hz}, 1 \mathrm{H}), 7.51-7.10(\mathrm{~m}, 4 \mathrm{H}), 6.33(\mathrm{~d}, J=2.2 \mathrm{~Hz}, 1 \mathrm{H}), 5.80(\mathrm{~s}, 1 \mathrm{H}), 5.38(\mathrm{~d}, J=5.8 \mathrm{~Hz}$, $1 \mathrm{H}), 4.93(\mathrm{dd}, J=5.8,2.4 \mathrm{~Hz}, 1 \mathrm{H}), 4.74(\mathrm{~s}, 2 \mathrm{H}), 4.60(\mathrm{~d}, J=2.8 \mathrm{~Hz}, 2 \mathrm{H}), 4.32(\mathrm{~s}, 1 \mathrm{H}), 3.85-3.40(\mathrm{~m}, 2 \mathrm{H})$, $2.81(\mathrm{~s}, 1 \mathrm{H}), 1.53(\mathrm{~s}, 3 \mathrm{H}), 1.40(\mathrm{~s}, 3 \mathrm{H}), 1.35(\mathrm{~d}, J=4.9 \mathrm{~Hz}, 12 \mathrm{H}), 0.92-0.68(\mathrm{~m}, 6 \mathrm{H}) .{ }^{13} \mathrm{C} \mathrm{NMR}(75 \mathrm{MHz}$, DMSO- $\left.d_{6}\right) \delta 170.11,155.15,147.21,144.93,138.31,136.41,133.28,128.44,127.72,127.65,125.03,123.75$, $119.93,113.01,91.27,83.71,83.52,81.08,78.85,77.71,71.73,70.36,60.37,28.30,26.87,25.62,25.25,24.46$, 15.74, 11.71. HRMS (ESI): $m / z$ calcd. for $\mathrm{C}_{34} \mathrm{H}_{44} \mathrm{~N}_{5} \mathrm{O}_{12} \mathrm{~S}$ [M-H] $]^{-}:$746.2712; found, 746.2712.

5.1.36. (2R,3S,4S,5R)-(6-(7-Amino-5-Methyl-1H-benzo[d]imidazol-1-yl)-2,2-

Dimethyltetrahydrofuro[3,4-d][1,3]dioxol-4-yl)methyl ((Tert-Butoxycarbonyl)glycyl)sulfamate (31a)

To a solution of compound 30a $(140 \mathrm{mg}, 0.187 \mathrm{mmol})$ in methanol $(20 \mathrm{~mL})$ was added $69 \mathrm{mg}$ of $\mathrm{Pd} / \mathrm{C}$ under argon, after which the argon was exchanged for hydrogen and the mixture was stirred at rt overnight. TLC analysis indicated the reaction to be completed, the $\mathrm{Pd} / \mathrm{C}$ was filtered, and the filtrate was concentrated. The residue was adsorbed on silica, and title compound 31a was purified by chromatography (MeOH/EA, 1:9) with an $84 \%$ yield (95 mg). ${ }^{1} \mathrm{H}$ NMR $\left(300 \mathrm{MHz}, \mathrm{CD}_{3} \mathrm{OD}\right) \delta=8.31$ $(\mathrm{s}, 1 \mathrm{H}), 6.89(\mathrm{dd}, J=1.5,0.9 \mathrm{~Hz}, 1 \mathrm{H}), 6.59(\mathrm{~s}, 1 \mathrm{H}), 6.20(\mathrm{~d}, J=4.2 \mathrm{~Hz}, 1 \mathrm{H}), 5.30-5.05(\mathrm{~m}, 2 \mathrm{H}), 4.47$ 
$(\mathrm{t}, J=3.1 \mathrm{~Hz}, 1 \mathrm{H}), 4.28(\mathrm{dd}, J=5.5,3.2 \mathrm{~Hz}, 2 \mathrm{H}), 3.69(\mathrm{~s}, 2 \mathrm{H}), 3.37(\mathrm{~s}, 1 \mathrm{H}), 3.33(\mathrm{p}, J=1.6 \mathrm{~Hz}, 2 \mathrm{H}), 2.36$ $(\mathrm{t}, J=0.6 \mathrm{~Hz}, 3 \mathrm{H}), 1.61(\mathrm{~s}, 3 \mathrm{H}), 1.44(\mathrm{~d}, J=1.7 \mathrm{~Hz}, 10 \mathrm{H}), 1.39(\mathrm{~s}, 3 \mathrm{H}) .{ }^{13} \mathrm{C}$ NMR $\left(75 \mathrm{MHz}, \mathrm{CD}_{3} \mathrm{OD}\right) \delta$ 176.21, 156.48, 144.88, 141.33, 133.48, 133.31, 120.29, 114.92, 111.86, 108.59, 91.51, 83.37, 82.20, 79.86, 78.40, $66.53,45.02,27.05,25.59,23.81,19.84$. HRMS (ESI): $m / z$ calcd. for $\mathrm{C}_{23} \mathrm{H}_{32} \mathrm{~N}_{5} \mathrm{O}_{9} \mathrm{~S}[\mathrm{M}-\mathrm{H}]^{-}: 554.1926$; found, 554.1924 .

5.1.37. (2R,3S,4S,5R)-(6-(7-Amino-5-(Hydroxymethyl)-1H-Benzo[d]imidazol-1-yl)-2,2-

Dimethyltetrahydrofuro[3,4-d][1,3]dioxol-4-yl)methyl ((Tert-Butoxycarbonyl)tyrosyl)sulfamate (31b)

This compound was synthesized in analogy to 31a starting from $400 \mathrm{mg}(0.62 \mathrm{mmol})$ of $30 \mathrm{~b}$. Yield: 98\%. ${ }^{1} \mathrm{H}$ NMR $\left(300 \mathrm{MHz}, \mathrm{DMSO}-d_{6}\right) \delta 9.07(\mathrm{~d}, J=2.0 \mathrm{~Hz}, 1 \mathrm{H}), 8.31(\mathrm{~d}, J=2.0 \mathrm{~Hz}, 1 \mathrm{H}), 7.07-6.86$ $(\mathrm{m}, 3 \mathrm{H}), 6.61(\mathrm{dd}, J=8.5,2.1 \mathrm{~Hz}, 3 \mathrm{H}), 6.24(\mathrm{~s}, 1 \mathrm{H}), 6.04(\mathrm{~d}, J=8.2 \mathrm{~Hz}, 1 \mathrm{H}), 5.17(\mathrm{~s}, 1 \mathrm{H}), 5.10-4.80(\mathrm{~m}, 4 \mathrm{H})$, $4.58-4.42(\mathrm{~m}, 2 \mathrm{H}), 4.35(\mathrm{~s}, 1 \mathrm{H}), 4.04-3.75(\mathrm{~m}, 3 \mathrm{H}), 2.93(\mathrm{~d}, J=13.7 \mathrm{~Hz}, 1 \mathrm{H}), 2.81-2.60(\mathrm{~m}, 1 \mathrm{H}), 1.55$ $(\mathrm{d}, J=2.0 \mathrm{~Hz}, 3 \mathrm{H}), 1.33(\mathrm{~d}, J=2.0 \mathrm{~Hz}, 12 \mathrm{H}) .{ }^{13} \mathrm{C}$ NMR $\left(75 \mathrm{MHz}, \mathrm{DMSO}-d_{6}\right) \delta 175.99,155.57,154.98$, $145.87,142.25,137.98,134.27,130.30,128.99,121.60,114.77,114.32,109.18,107.24,90.37,83.38,82.36$, 80.25, 77.56, 66.24, 63.55, 57.94, 37.30, 28.37, 27.01, 25.33. HRMS (ESI): $\mathrm{m} / z$ calcd. for $\mathrm{C}_{30} \mathrm{H}_{38} \mathrm{~N}_{5} \mathrm{O}_{11} \mathrm{~S}$ $[\mathrm{M}-\mathrm{H}]^{-}:$: 676.2294; found, 676.2291.

5.1.38. (2R,3S,4S,5R)-(6-(7-Amino-5-(Hydroxymethyl)-1H-Benzo[d]imidazol-1-yl)-2,2Dimethyltetrahydrofuro[3,4-d][1,3]dioxol-4-yl)methyl ((Tert-Butoxycarbonyl)seryl)sulfamate (31c)

This compound was synthesized in analogy to 31a starting from $500 \mathrm{mg}(0.62 \mathrm{mmol})$ of 30c. Yield: 80\%. ${ }^{1} \mathrm{H}$ NMR $\left(300 \mathrm{MHz}\right.$, DMSO- $\left.d_{6}\right) \delta 8.30(\mathrm{~s}, 1 \mathrm{H}), 6.93(\mathrm{~d}, J=1.3 \mathrm{~Hz}, 1 \mathrm{H}), 6.61(\mathrm{~d}, J=1.3 \mathrm{~Hz}, 1 \mathrm{H}), 6.23$ $(\mathrm{d}, J=3.9 \mathrm{~Hz}, 1 \mathrm{H}), 6.05(\mathrm{~d}, J=7.9 \mathrm{~Hz}, 1 \mathrm{H}), 5.76(\mathrm{~s}, 1 \mathrm{H}), 5.25-5.08(\mathrm{~m}, 1 \mathrm{H}), 5.08-4.96(\mathrm{~m}, 2 \mathrm{H}), 4.80(\mathrm{~d}, 3 \mathrm{H})$, $4.46(\mathrm{~d}, J=5.4 \mathrm{~Hz}, 2 \mathrm{H}), 4.34(\mathrm{q}, J=4.0 \mathrm{~Hz}, 1 \mathrm{H}), 4.01-3.84(\mathrm{~m}, 1 \mathrm{H}), 3.82-3.67(\mathrm{~m}, 1 \mathrm{H}), 3.58(\mathrm{~d}, J=4.4 \mathrm{~Hz}$, $2 \mathrm{H}), 2.60(\mathrm{~s}, 1 \mathrm{H}), 1.55(\mathrm{~s}, 3 \mathrm{H}), 1.35(\mathrm{~d}, J=17.8 \mathrm{~Hz}, 12 \mathrm{H}) .{ }^{13} \mathrm{C}$ NMR $\left(75 \mathrm{MHz}\right.$, DMSO- $\left.d_{6}\right) \delta 174.73,155.13$, $145.87,142.28,137.97,134.29,121.60,114.28,109.15,107.22,90.40,83.36,82.33,80.26,77.80,66.04,63.55$, 62.94, 58.57, 28.38, 27.01, 25.33. HRMS (ESI): $m / z$ calcd. for $\mathrm{C}_{24} \mathrm{H}_{34} \mathrm{~N}_{5} \mathrm{O}_{11} \mathrm{~S}[\mathrm{M}-\mathrm{H}]^{-}:$600.1981; found, 600.1983.

5.1.39. Tert-Butyl 4-(((6-(7-Amino-5-(Hydroxymethyl)-1H-Benzo[d]imidazol-1-yl)-2,2Dimethyltetrahydrofuro[3,4-d][1,3]dioxol-4-yl)methoxy)sulfonyl)amino)-3-((Tert-Butoxycarbonyl) amino)-4-Oxobutanoate (31d)

This compound was synthesized in analogy to 31a starting from $460 \mathrm{mg}(0.57 \mathrm{mmol})$ of 30d. Yield: 68\%. ${ }^{1} \mathrm{H}$ NMR $\left(300 \mathrm{MHz}, \mathrm{DMSO}-d_{6}\right) \delta 8.31(\mathrm{~s}, 1 \mathrm{H}), 6.93(\mathrm{~s}, 1 \mathrm{H}), 6.62(\mathrm{~s}, 1 \mathrm{H}), 6.33(\mathrm{~d}, J=8.5 \mathrm{~Hz}, 1 \mathrm{H}), 6.23$ $(\mathrm{d}, J=4.0 \mathrm{~Hz}, 1 \mathrm{H}), 5.17(\mathrm{dd}, J=6.6,4.0 \mathrm{~Hz}, 1 \mathrm{H}), 5.00(\mathrm{dd}, J=8.6,5.6 \mathrm{~Hz}, 3 \mathrm{H}), 4.46(\mathrm{~d}, J=5.0 \mathrm{~Hz}, 2 \mathrm{H})$, $4.34(\mathrm{~d}, J=3.8 \mathrm{~Hz}, 1 \mathrm{H}), 4.06(\mathrm{~d}, J=7.1 \mathrm{~Hz}, 1 \mathrm{H}), 3.91(\mathrm{dd}, J=11.1,4.6 \mathrm{~Hz}, 1 \mathrm{H}), 2.64(\mathrm{dd}, J=15.0,4.7 \mathrm{~Hz}$, $1 \mathrm{H}), 2.36(\mathrm{dd}, J=15.1,8.5 \mathrm{~Hz}, 1 \mathrm{H}), 1.55(\mathrm{~s}, 3 \mathrm{H}), 1.52-1.27(\mathrm{~m}, 21 \mathrm{H}) .{ }^{13} \mathrm{C}$ NMR $\left(75 \mathrm{MHz}\right.$, DMSO- $\left.d_{6}\right) \delta$ 175.05, 155.03, 145.72, 142.18, 138.03, 134.30, 121.58, 114.27, 109.19, 107.17, 99.65, 90.41, 83.35, 82.41, 80.30, 79.61, 77.72, 66.19, 63.53, 53.56, 28.37, 27.85, 27.01, 25.31. HRMS (ESI): $m / z$ calcd for $\mathrm{C}_{29} \mathrm{H}_{42} \mathrm{~N}_{5} \mathrm{O}_{12} \mathrm{~S}$ $[\mathrm{M}-\mathrm{H}]^{-}:$684.2556; found, 684.2569 .

5.1.40. (2R,3S,4S,5R)-(6-(7-Amino-5-(Hydroxymethyl)-1H-Benzo[d]imidazol-1-yl)-2,2Dimethyltetrahydrofuro[3,4-d][1,3]dioxol-4-yl)methyl ((Tert-Butoxycarbonyl)leucyl)sulfamate (31e)

This compound was synthesized in analogy to 31a starting from $200 \mathrm{mg}(0.27 \mathrm{mmol})$ of 30e. Yield: $80 \% .{ }^{1} \mathrm{H}$ NMR $\left(300 \mathrm{MHz}\right.$, DMSO- $\left.d_{6}\right) \delta 11.97(\mathrm{~s}, 1 \mathrm{H}), 8.30(\mathrm{~s}, 1 \mathrm{H}), 6.92(\mathrm{~d}, J=1.3 \mathrm{~Hz}, 1 \mathrm{H}), 6.61(\mathrm{~s}, 1 \mathrm{H})$, $6.22(\mathrm{~d}, J=3.9 \mathrm{~Hz}, 1 \mathrm{H}), 6.14(\mathrm{~d}, J=8.5 \mathrm{~Hz}, 1 \mathrm{H}), 5.16(\mathrm{dd}, J=6.7,4.0 \mathrm{~Hz}, 1 \mathrm{H}), 5.10-4.75(\mathrm{~m}, 2 \mathrm{H}), 4.46(\mathrm{~d}$, $J=5.6 \mathrm{~Hz}, 2 \mathrm{H}), 4.39-4.24(\mathrm{~m}, 1 \mathrm{H}), 4.02-3.84(\mathrm{~m}, 2 \mathrm{H}), 3.76(\mathrm{~d}, J=5.1 \mathrm{~Hz}, 1 \mathrm{H}), 3.18(\mathrm{~d}, J=4.4 \mathrm{~Hz}, 1 \mathrm{H})$, $1.91(\mathrm{~s}, 2 \mathrm{H}), 1.55(\mathrm{~s}, 3 \mathrm{H}), 1.34(\mathrm{~d}, J=12.9 \mathrm{~Hz}, 12 \mathrm{H}), 0.85(\mathrm{dd}, J=6.5,1.5 \mathrm{~Hz}, 8 \mathrm{H}) .{ }^{13} \mathrm{C}$ NMR $(75 \mathrm{MHz}$, DMSO- $\left.d_{6}\right) \delta 177.25,155.23,145.89,142.22,137.95,134.26,121.61,114.25,109.14,107.25,90.35,83.35$, $82.37,80.28,77.50,66.12,63.54,55.03,42.50,28.39,27.01,25.34,24.56,23.33,21.96$. HRMS (ESI): $m / z$ calcd. for $\mathrm{C}_{27} \mathrm{H}_{40} \mathrm{~N}_{5} \mathrm{O}_{10} \mathrm{~S}[\mathrm{M}+\mathrm{H}]^{+}$: 628.2647; found, 628.2656. 
5.1.41. (2R,3S,4S,5R)-(6-(7-Amino-5-(Hydroxymethyl)-1H-Benzo[d]imidazol-1-yl)-2,2-

Dimethyltetrahydrofuro[3,4-d][1,3]dioxol-4-yl)methyl ((Tert-Butoxycarbonyl)isoleucyl)sulfamate (31f)

This compound was synthesized in analogy to 31a starting from $140 \mathrm{mg}(0.176 \mathrm{mmol})$ of $30 \mathrm{f}$. Yield: 85\%. ${ }^{1} \mathrm{H}$ NMR (300 MHz, DMSO- $\left.d_{6}\right) \delta 8.31(\mathrm{~s}, 1 \mathrm{H}), 6.93(\mathrm{~s}, 1 \mathrm{H}), 6.62(\mathrm{~d}, J=1.3 \mathrm{~Hz}, 1 \mathrm{H}), 6.23$ $(\mathrm{d}, J=3.9 \mathrm{~Hz}, 1 \mathrm{H}), 5.87(\mathrm{~d}, J=8.4 \mathrm{~Hz}, 1 \mathrm{H}), 5.09(\mathrm{dd}, J=6.7,3.7 \mathrm{~Hz}, 3 \mathrm{H}), 4.46(\mathrm{~d}, J=4.8 \mathrm{~Hz}, 2 \mathrm{H}), 4.36$ $(\mathrm{t}, J=3.9 \mathrm{~Hz}, 1 \mathrm{H}), 3.96(\mathrm{dd}, J=12.1,7.4 \mathrm{~Hz}, 1 \mathrm{H}), 3.67(\mathrm{dd}, J=8.5,5.0 \mathrm{~Hz}, 1 \mathrm{H}), 1.72(\mathrm{~s}, 1 \mathrm{H}), 1.55(\mathrm{~s}, 3 \mathrm{H})$, $1.35(\mathrm{~d}, J=15.0 \mathrm{~Hz}, 12 \mathrm{H}), 1.05(\mathrm{dt}, J=15.3,7.8 \mathrm{~Hz}, 1 \mathrm{H}), 0.79(\mathrm{dt}, J=7.5,4.0 \mathrm{~Hz}, 7 \mathrm{H}) .{ }^{13} \mathrm{C} \mathrm{NMR}(75 \mathrm{MHz}$, DMSO-d $)_{6} \delta 175.79,155.19,145.86,142.17,137.96,134.25,121.61,114.28,109.16,107.25,99.66,90.34$, $83.37,82.35,80.27,77.71,66.33,63.54,60.58,59.88,38.14,28.33,26.98,25.29,24.45,15.84,11.78$. HRMS (ESI): $m / z$ calcd. for $\mathrm{C}_{27} \mathrm{H}_{40} \mathrm{~N}_{5} \mathrm{O}_{10} \mathrm{~S}[\mathrm{M}-\mathrm{H}]^{-}$: 626.2501; found, 626.2496.

5.1.42. (2R,3S,4S,5R)-(5-(7-Amino-5-Methyl-1H-Benzo[d]imidazol-1-yl)-3,4Dihydroxytetrahydrofuran-2-yl)methyl Glycylsulfamate (32a)

Compound 31a (60 mg, $0.11 \mathrm{mmol})$ was dissolved in a mixture of TFA and $\mathrm{H}_{2} \mathrm{O}(7 \mathrm{~mL}, 5: 2 \mathrm{v} / \mathrm{v})$, and the reaction mixture was stirred for $40 \mathrm{~min}$. After reaction, the volatiles were evaporated under reduced pressure, followed by co-evaporation with $\mathrm{EtOH}$, and once more with $\mathrm{EtOH}+1 \mathrm{~mL} \mathrm{Et}_{3} \mathrm{~N}$ to neutralize any remaining acid. The title compound 32a was obtained by reversed phase-HPLC as a white solid with a $60 \%$ yield. ${ }^{1} \mathrm{H}$ NMR $\left(300 \mathrm{MHz}, \mathrm{D}_{2} \mathrm{O}\right) \delta 8.20(\mathrm{~s}, 1 \mathrm{H}), 6.87(\mathrm{~s}, 1 \mathrm{H}), 6.50(\mathrm{~s}, 1 \mathrm{H}), 6.00$ $(\mathrm{d}, J=6.0 \mathrm{~Hz}, 1 \mathrm{H}), 4.53(\mathrm{t}, J=5.8 \mathrm{~Hz}, 1 \mathrm{H}), 4.32(\mathrm{~m}, 5 \mathrm{H}), 3.54(\mathrm{~s}, 2 \mathrm{H}), 2.22(\mathrm{~s}, 3 \mathrm{H}) .{ }^{13} \mathrm{C} \mathrm{NMR}(75 \mathrm{MHz}$, $\left.\mathrm{D}_{2} \mathrm{O}\right) \delta 172.34,143.71,141.14,134.52,131.91,120.76,113.15,109.54,88.63,81.94,73.22,69.30,67.80,42.43$, 20.03. HRMS (ESI): $m / z$ calcd. for $\mathrm{C}_{15} \mathrm{H}_{22} \mathrm{~N}_{5} \mathrm{O}_{7} \mathrm{~S}[\mathrm{M}+\mathrm{H}]^{+}$: 416.1234; found, 416.1223 .

5.1.43. (2R,3S,4S,5R)-(5-(7-Amino-5-(Hydroxymethyl)-1H-Benzo[d]imidazol-1-yl)-3,4Dihydroxytetrahydrofuran-2-yl)methyl Tyrosylsulfamate (32b)

This compound was synthesized in analogy to 32a starting from $300 \mathrm{mg}(0.44 \mathrm{mmol})$ of $\mathbf{3 1 b}$. Yield: 80\%. ${ }^{1} \mathrm{H}$ NMR (300 MHz, $\left.\mathrm{D}_{2} \mathrm{O}\right) \delta 8.67(\mathrm{~s}, 1 \mathrm{H}), 7.09-6.82(\mathrm{~m}, 3 \mathrm{H}), 6.81-6.50(\mathrm{~m}, 3 \mathrm{H}), 6.18(\mathrm{~d}, \mathrm{~J}=2.9 \mathrm{~Hz}$, $1 \mathrm{H}), 4.61-4.08(\mathrm{~m}, 7 \mathrm{H}), 3.84(\mathrm{t}, J=6.6 \mathrm{~Hz}, 1 \mathrm{H}), 2.86(\mathrm{qd}, J=14.4,6.0 \mathrm{~Hz}, 2 \mathrm{H}) .{ }^{13} \mathrm{C} \mathrm{NMR}\left(75 \mathrm{MHz}, \mathrm{D}_{2} \mathrm{O}\right)$ $\delta 174.41,154.49,139.14,138.81,137.11,133.45,130.41,125.58,120.65,115.21,112.16,105.07,89.76,82.61$, 74.07, 69.49, 67.68, 63.14, 56.24, 35.47. HRMS (ESI): $m / z$ calcd. for $\mathrm{C}_{22} \mathrm{H}_{26} \mathrm{~N}_{5} \mathrm{O}_{9} \mathrm{~S}[\mathrm{M}-\mathrm{H}]^{-}:$536.1457; found, 536.1452 .

5.1.44. (2R,3S,4S,5R)-(5-(7-Amino-5-(Hydroxymethyl)-1H-Benzo[d]imidazol-1-yl)-3,4Dihydroxytetrahydrofuran-2-yl)methyl Serylsulfamate (32c)

This compound was synthesized in analogy to 32a starting from $115 \mathrm{mg}(0.19 \mathrm{mmol})$ of 31c. Yield: 62\%. ${ }^{1} \mathrm{H}$ NMR (300 MHz, D $\left.2 \mathrm{O}\right) \delta 8.47(\mathrm{~s}, 1 \mathrm{H}), 6.98(\mathrm{~d}, J=1.4 \mathrm{~Hz}, 1 \mathrm{H}), 6.65(\mathrm{~d}, J=1.4 \mathrm{~Hz}, 1 \mathrm{H}), 6.05(\mathrm{dd}$, $J=5.8,1.3 \mathrm{~Hz}, 1 \mathrm{H}), 4.52(\mathrm{~d}, J=8.4 \mathrm{~Hz}, 3 \mathrm{H}), 4.42-4.17(\mathrm{~m}, 4 \mathrm{H}), 3.99-3.69(\mathrm{~m}, 3 \mathrm{H}) .{ }^{13} \mathrm{C} \mathrm{NMR}(75 \mathrm{MHz}$, $\left.\mathrm{D}_{2} \mathrm{O}\right) \delta 172.83,140.46,140.26,137.76,132.93,121.36,111.56,106.78,89.12,82.33,73.59,69.39,67.80,63.35$, 59.94, 56.67. HRMS (ESI): $m / z$ calcd. for $\mathrm{C}_{16} \mathrm{H}_{22} \mathrm{~N}_{5} \mathrm{O}_{9} \mathrm{~S}[\mathrm{M}-\mathrm{H}]^{-}:$460.1144; found, 460.1146 .

5.1.45. 3-Amino-4-(((5-(7-Amino-5-(Hydroxymethyl)-1H-Benzo[d]imidazol-1-yl)-3,4Dihydroxytetrahydrofuran-2-yl)methoxy)sulfonyl)amino)-4-Oxobutanoic Acid (32d)

This compound was synthesized in analogy to 32a starting from $120 \mathrm{mg}(0.18 \mathrm{mmol})$ of 31d. Yield: 48\%. ${ }^{1} \mathrm{H}$ NMR (300 MHz, D $\left.2 \mathrm{O}\right) \delta 9.19(\mathrm{~s}, 1 \mathrm{H}), 7.13(\mathrm{~s}, 1 \mathrm{H}), 6.89(\mathrm{~s}, 1 \mathrm{H}), 6.33(\mathrm{~d}, J=4.9 \mathrm{~Hz}, 1 \mathrm{H}), 4.70-4.20$ $(\mathrm{m}, 7 \mathrm{H}), 3.98(\mathrm{t}, J=5.3 \mathrm{~Hz}, 1 \mathrm{H}), 2.90(\mathrm{~d}, J=5.4 \mathrm{~Hz}, 2 \mathrm{H}) .{ }^{13} \mathrm{C} \mathrm{NMR}\left(75 \mathrm{MHz}, \mathrm{D}_{2} \mathrm{O}\right) \delta 173.71,173.43$, 140.87, 137.35, 134.06, 133.04, 119.85, 117.95, 114.08, 112.91, 103.02, 90.54, 83.20, 74.53, 69.74, 67.62, 62.90, 51.41, 34.36. HRMS (ESI): $m / z$ calcd. for $\mathrm{C}_{17} \mathrm{H}_{22} \mathrm{~N}_{5} \mathrm{O}_{10} \mathrm{~S}[\mathrm{M}-\mathrm{H}]^{-}:$488.1093; found, 488.1064 .

5.1.46. (2R,3S,4S,5R)-(5-(7-Amino-5-(Hydroxymethyl)-1H-Benzo[d]imidazol-1-yl)-3,4Dihydroxytetrahydrofuran-2-yl)methyl Leucylsulfamate (32e)

This compound was synthesized in analogy to 32a starting from $80 \mathrm{mg}(0.13 \mathrm{mmol})$ of 31e. Yield: 82\%. ${ }^{1} \mathrm{H}$ NMR (300 MHz, D $\left.2 \mathrm{O}\right) \delta 8.26(\mathrm{~d}, J=2.3 \mathrm{~Hz}, 1 \mathrm{H}), 7.10(\mathrm{~d}, J=1.9 \mathrm{~Hz}, 1 \mathrm{H}), 6.70(\mathrm{q}, J=1.4 \mathrm{~Hz}$, 
1H), $6.06(\mathrm{dd}, J=6.6,2.3 \mathrm{~Hz}, 1 \mathrm{H}), 4.64-4.19(\mathrm{~m}, 7 \mathrm{H}), 3.59(\mathrm{td}, J=5.4,2.5 \mathrm{~Hz}, 1 \mathrm{H}), 1.66-1.21(\mathrm{~m}, 3 \mathrm{H}), 0.71$ $(\mathrm{dd}, J=6.0,2.1 \mathrm{~Hz}, 6 \mathrm{H}) .{ }^{13} \mathrm{C}$ NMR $\left(75 \mathrm{MHz}, \mathrm{D}_{2} \mathrm{O}\right) \delta 176.02,144.13,141.89,136.45,132.51,122.55,111.30$, $108.93,88.19,82.12,73.10,69.52,68.03,63.60,53.80,39.81,23.62,21.39,20.41$. HRMS (ESI): $\mathrm{m} / \mathrm{z}$ calcd. for $\mathrm{C}_{19} \mathrm{H}_{28} \mathrm{~N}_{5} \mathrm{O}_{8} \mathrm{~S}[\mathrm{M}-\mathrm{H}]^{-}:$486.1664; found, 486.1666 .

5.1.47. (2R,3S,4S,5R)-(5-(7-Amino-5-(Hydroxymethyl)-1H-Benzo[d]imidazol-1-yl)-3,4Dihydroxytetrahydrofuran-2-yl)methyl Isoleucylsulfamate (32f)

This compound was synthesized in analogy to 32a starting from $158 \mathrm{mg}(0.25 \mathrm{mmol})$ of 31f. Yield: 84\%. ${ }^{1} \mathrm{H}$ NMR (300 MHz, D $\left.2 \mathrm{O}\right) \delta 8.35(\mathrm{~s}, 1 \mathrm{H}), 7.12(\mathrm{~s}, 1 \mathrm{H}), 6.74(\mathrm{~d}, J=1.3 \mathrm{~Hz}, 1 \mathrm{H}), 6.10(\mathrm{~d}, J=6.5 \mathrm{~Hz}$, $1 \mathrm{H}), 4.67-4.19(\mathrm{~m}, 7 \mathrm{H}), 3.54(\mathrm{dd}, J=4.3,1.2 \mathrm{~Hz}, 1 \mathrm{H}), 3.11(\mathrm{~d}, J=7.3 \mathrm{~Hz}, 1 \mathrm{H}), 1.76(\mathrm{~s}, 1 \mathrm{H}), 1.37-1.09$ $(\mathrm{m}, 2 \mathrm{H}), 1.09-0.54(\mathrm{~m}, 6 \mathrm{H}) .{ }^{13} \mathrm{C} \mathrm{NMR}\left(75 \mathrm{MHz}, \mathrm{D}_{2} \mathrm{O}\right) \delta 174.77,144.16,141.79,136.43,132.51,122.59$, 111.24, 108.92, 88.14, 82.12, 73.06, 69.59, 68.05, 63.61, 59.73, 35.97, 23.63, 14.02, 10.44. HRMS (ESI): $m / z$ calcd. for $\mathrm{C}_{19} \mathrm{H}_{28} \mathrm{~N}_{5} \mathrm{O}_{8} \mathrm{~S}[\mathrm{M}-\mathrm{H}]^{-}$: 486.1664; found, 486.1664 .

\subsection{Preparation of Different Aminoacyl tRNA Synthetases}

The cloning, expression and purification of all aaRSs were performed as previously described $[3,25,29]$.

\subsection{Radiolabel Aminoacyl Transfer Assay Using Purified E. coli aaRSs}

The general method and procedures were carried out according to Zhang et al. [3] and Nautiyal et al. [25]. The aminoacylation assay was performed with following enzyme concentrations and reaction times: AspRS (2 nM; $3 \mathrm{~min})$; SerRS (2 nM; $6 \mathrm{~min})$; TyrRS (0.5 nM; $8 \mathrm{~min})$; LeuRS (2.5 nM; $4 \mathrm{~min}$ ); IleRS (10 $\mathrm{nM} ; 6 \mathrm{~min})$.

\subsection{Crystallization, Data Collection and Structure Determination}

The crystallization procedures for Neisseria gonorrhoeae LeuRS, E. coli TyrRS, Klebsiella pneumoniae SerRS and Thermus thermophilus AspRS were carried out as described in our previous work [25,29]. Suitable crystals were soaked with the respective synthesized aaS7HMDDA inhibitors in the corresponding cryo-protectant solution before being flash frozen in liquid nitrogen.

All the X-ray diffraction datasets of the aaRS-inhibitor complexes were collected at synchrotron facilities. The datasets were processed by applying the autoproc package [33]. The structures were initially solved by molecular replacement with PHASER using our previously published aaSA-bound aaRS structures as the search models. Briefly, Protein Data Bank (PDB) structures 6Q89, 6I5Y, 6H9X and 6SJC were used as the model for LeuRS, TyrRS, SerRS and AspRS, respectively. After initial refinement, the molecular replacement solution was completed manually in COOT [34] and refined in Phenix. Structure quality was analyzed by PDB validation. The crystallographic data collection and refinement statistics are presented in Table 2.

Supplementary Materials: The following are available online. Molecules-960294-Supporting Information-final.pdf.

Author Contributions: B.Z. designed and performed all the chemistry experiments and analyzed experimental data; B.G. assisted in chemical supervision and data interpretation; L.P. and S.D.G. provided all the purified enzymes and carried out the structural work; L.P. and M.N. carried out the in vitro biological evaluations; E.L. supervised all the NMR analyses and performed 2D analysis; J.R. provided MS analysis; S.V.S. and S.D.W. conceived and supervised all the biological and structural work; A.V.A. designed and supervised the overall work; B.Z., L.P. and A.V.A. wrote the manuscript. All authors have read and agreed to the published version of the manuscript.

Funding: This work was supported by the Research Foundation-Flanders (Fonds voor Wetenschappelijk Onderzoek, grants G077814N to S.V.S. and A.V.A., and G0A4616N to S.D.W. and A.V.A.) and the KU Leuven Research Fund (grant 3M14022 to S.D.W. and A.V.A.). Mass spectrometry was made possible by the support of the Hercules Foundation of the Flemish Government (20100225E7). The APC was funded from grant G0A4616N. 
Acknowledgments: The authors thank the China Scholarship Council for providing a scholarship to Baole Zhang and Luping Pang, and the Research Foundation-Flanders for providing an SB Fellowship to Steff De Graef $(1 \mathrm{~S} 53516 \mathrm{~N})$ and a postdoctoral fellowship to Bharat Gadakh (12A3916N). We further greatly appreciate the support from the beamline scientists at the PROXIMA 1 and PROXIMA 2 (Soleil Synchrotron, France) and ID29 (ESRF, France) beamlines. We are also indebted to Chantal Biernaux for editorial assistance.

Conflicts of Interest: No conflicts of interest are declared.

\section{References}

1. Vondenhoff, G.H.M.; Van Aerschot, A. Aminoacyl-tRNA synthetase inhibitors as potential antibiotics. Eur. J. Med. Chem. 2011, 46, 5227-5236. [CrossRef] [PubMed]

2. Eriani, G.; Delarue, M.; Poch, O.; Gangloff, J.; Moras, D. Partition of tRNA synthetases into two classes based on mutually exclusive sets of sequence motifs. Nature 1990, 347, 203-206. [CrossRef]

3. Zhang, B.; De Graef, S.; Nautiyal, M.; Pang, L.; Gadakh, B.; Froeyen, M.; Van Mellaert, L.; Strelkov, S.V.; Weeks, S.D.; Van Aerschot, A. Family-wide analysis of aminoacyl-sulfamoyl-3-deazaadenosine analogues as inhibitors of aminoacyl-tRNA synthetases. Eur. J. Med. Chem. 2018, 148, 384-396. [CrossRef]

4. Redwan, I.N.; Ljungdahl, T.; Grøtli, M. Investigation, optimization and synthesis of sulfamoyloxy-linked aminoacyl-AMP analogues. Tetrahedron 2012, 68, 1507-1514. [CrossRef]

5. Shi, C.; Tiwari, D.; Wilson, D.J.; Seiler, C.L.; Schnappinger, D.; Aldrich, C.C. Bisubstrate Inhibitors of Biotin Protein Ligase in Mycobacterium tuberculosis Resistant to Cyclonucleoside Formation. ACS Med. Chem. Lett. 2013, 4, 1213-1217. [CrossRef] [PubMed]

6. Gadakh, B.; Vondenhoff, G.; Lescrinier, E.; Rozenski, J.; Froeyen, M.; Van Aerschot, A. Base substituted 5'-O-(N-isoleucyl)sulfamoyl nucleoside analogues as potential antibacterial agents. Bioorg. Med. Chem. 2014, 22, 2875-2886. [CrossRef] [PubMed]

7. Lee, J.; Kim, S.E.; Lee, J.Y.; Kim, S.Y.; Kang, S.U.; Seo, S.H.; Chun, M.W.; Kang, T.; Choi, S.Y.; Kim, H.O. $\mathrm{N}$-Alkoxysulfamide, $\mathrm{N}$-hydroxysulfamide, and sulfamate analogues of methionyl and isoleucyl adenylates as inhibitors of methionyl-tRNA and isoleucyl-tRNA synthetases. Bioorg. Med. Chem. Lett. 2003, 13, 1087-1092. [CrossRef]

8. Zhang, H.-Z.; Rao, K.; Carr, S.F.; Papp, E.; Straub, K.; Wu, J.C.; Fried, J. Rationally Designed Inhibitors of Inosine Monophosphate Dehydrogenase. J. Med. Chem. 1997, 40, 4-8. [CrossRef]

9. Bonhôte, P.; Wrighton, M.S. Facile Synthesis of Tetrapyrido[2,3-a:3', 2'-c:2", $\left.3^{\prime \prime}-\mathrm{h}: 3^{\prime \prime \prime}, 2^{\prime \prime \prime}-\mathrm{j}\right]$ phenazine. Synlett 1997, 1997, 897-898. [CrossRef]

10. Nair, V.; Purdy, D.F.; Sells, T.B. Synthesis of congeners of adenosine resistant to deamination by adenosine deaminase. J. Chem. Soc. Chem. Commun. 1989, 13, 878-879. [CrossRef]

11. Nair, V.; Lyons, A.G. Novel unsaturated purine nucleosides. Tetrahedron 1989, 45, 3653-3662. [CrossRef]

12. Nair, V.; Ussery, M.A. New hypoxanthine nucleosides with RNA antiviral activity. Antivir. Res. 1992, 19, 173-178. [CrossRef]

13. Cain, R.; Salimraj, R.; Punekar, A.S.; Bellini, D.; Fishwick, C.W.G.; Czaplewski, L.; Scott, D.J.; Harris, G.; Dowson, C.G.; Lloyd, A.J.; et al. Structure-Guided Enhancement of Selectivity of Chemical Probe Inhibitors Targeting Bacterial Seryl-tRNA Synthetase. J. Med. Chem. 2019, 62, 9703-9717. [CrossRef] [PubMed]

14. Schimmel, P.; Tao, J.; Hill, J. Aminoacyl tRNA synthetases as targets for new anti-infectives. FASEB J. 1998, 12, 1599-1609. [CrossRef] [PubMed]

15. Zeng, Y.; Roy, H.; Patil, P.B.; Ibba, M.; Chen, S. Characterization of two seryl-tRNA synthetases in albomycin-producing streptomyces sp. Strain ATCC 700974. Antimicrob. Agents Chemother. 2009, 53, 4619-4627. [CrossRef] [PubMed]

16. Elkin, V.V.; Tolkacheva, L.N.; Chernysheva, N.B.; Karmanova, I.B.; Konyushkin, L.D.; Semenov, V.V. Hydrogenation on palladium containing granulated catalysts; 3. Synthesis of aminobenzimidazoles by catalytic hydrogenation of dinitroanilines. Russ. Chem. Bull. Int. Ed. 2007, 56, 1216-1226. [CrossRef]

17. Milata, V.; Saloň, J. Simple, high yield preparation of 3-nitro-1,2-phenylenediamine. Org. Prep. Proced. Int. 1999, 31, 347-348. [CrossRef]

18. Ida, Y.; Matsubara, A.; Nemoto, T.; Saito, M.; Hirayama, S.; Fujii, H.; Nagase, H. Synthesis of quinolinomorphinan derivatives as highly selective $\delta$ opioid receptor ligands. Bioorg. Med. Chem. 2012, 20, 5810-5831. [CrossRef] [PubMed] 
19. Pathak, A.K.; El-Kattan, Y.A.; Bansal, N.; Maddry, J.A.; Reynolds, R.C. Tin(IV) chloride mediated glycosylation in arabinofuranose, galactofuranose and rhamnopyranose. Tetrahedron Lett. 1998, 39, 1497-1500. [CrossRef]

20. Vorbrüggen, H.; Krolikiewicz, K.; Bennua, B. Nucleoside syntheses, XXII1) Nucleoside synthesis with trimethylsilyl triflate and perchlorate as catalysts. Chem. Ber. 1981, 114, 1234-1255. [CrossRef]

21. Ashcroft, C.P.; Dessi, Y.; Entwistle, D.A.; Hesmondhalgh, L.C.; Longstaff, A.; Smith, J.D. Route Selection and Process Development of a Multikilogram Route to the Inhaled A2a Agonist UK-432,097. Org. Process Res. Dev. 2012, 16, 470-483. [CrossRef]

22. Eckenberg, P.; Groth, U.; Huhn, T.; Richter, N.; Schmeck, C. A useful application of benzyl trichloroacetimidate for the benzylation of alcohols. Tetrahedron 1993, 49, 1619-1624. [CrossRef]

23. Ombouma, J.; Vullo, D.; Dumy, P.; Supuran, C.T.; Winum, J.-Y. Carbonic Anhydrase Glycoinhibitors belonging to the Aminoxysulfonamide Series. ACS Med. Chem. Lett. 2015, 6, 819-821. [CrossRef] [PubMed]

24. Copeland, R.A. Tight Binding Inhibition. In Evaluation of Enzyme Inhibitors in Drug Discovery; John Wiley \& Sons, Inc.: Hoboken, NJ, USA, 2013; pp. 245-285. [CrossRef]

25. Nautiyal, M.; De Graef, S.; Pang, L.; Gadakh, B.; Strelkov, S.V.; Weeks, S.D.; Van Aerschot, A. Comparative analysis of pyrimidine substituted aminoacyl-sulfamoyl nucleosides as potential inhibitors targeting class I aminoacyl-tRNA synthetases. Eur. J. Med. Chem. 2019, 173, 154-166. [CrossRef] [PubMed]

26. Adams, P.D.; Afonine, P.V.; Bunkoczi, G.; Chen, V.B.; Davis, I.W.; Echols, N.; Headd, J.J.; Hung, L.-W.; Kapral, G.J.; Grosse-Kunstleve, R.W.; et al. PHENIX: A comprehensive Python-based system for macromolecular structure solution. Acta Crystallogr. Sect. D Struct. Biol. 2010, 66, 213-221. [CrossRef] [PubMed]

27. Khoje, A.D.; Charnock, C.; Wan, B.; Franzblau, S.; Gundersen, L.-L. Synthesis and antimycobacterial activities of non-purine analogs of 6-aryl-9-benzylpurines: Imidazopyridines, pyrrolopyridines, benzimidazoles, and indoles. Bioorg. Med. Chem. 2011, 19, 3483-3491. [CrossRef] [PubMed]

28. Krajczyk, A.; Zeidler, J.; Januszczyk, P.; Dawadi, S.; Boshoff, H.I.; Barry, C.E., 3rd; Ostrowski, T.; Aldrich, C.C. 2-Aryl-8-aza-3-deazaadenosine analogues of 5'-O-[N-(salicyl)sulfamoyl]adenosine: Nucleoside antibiotics that block siderophore biosynthesis in Mycobacterium tuberculosis. Bioorg. Med. Chem. 2016, 24, 3133-3143. [CrossRef]

29. Pang, L.; Nautiyal, M.; De Graef, S.; Gadakh, B.; Zorzini, V.; Economou, A.; Strelkov, S.V.; Van Aerschot, A.; Weeks, S.D. Structural Insights into the Binding of Natural Pyrimidine-Based Inhibitors of Class II Aminoacyl-tRNA Synthetases. ACS Chem. Biol. 2020, 15, 407-415. [CrossRef]

30. Devlin, T.A.; Jebaratnam, D.J. An Improved Procedure for the Synthesis of 1,3-Dideazaadenosine. Synth. Commun. 1995, 25, 711-718. [CrossRef]

31. Boehr, D.D.; Farley, A.R.; LaRonde, F.J.; Murdock, T.R.; Wright, G.D.; Cox, J.R. Establishing the Principles of Recognition in the Adenine-Binding Region of an Aminoglycoside Antibiotic Kinase [APH( $\left(3^{\prime}\right)$-IIIa]. Biochemistry 2005, 44, 12445-12453. [CrossRef]

32. Townsend, A.P.; Roth, S.; Williams, H.E.; Stylianou, E.; Thomas, N.R. New S-adenosyl-L-methionine analogues: Synthesis and reactivity studies. Org. Lett. 2009, 11, 2976-2979. [CrossRef] [PubMed]

33. Vonrhein, C.; Flensburg, C.; Keller, P.; Sharff, A.; Smart, O.; Paciorek, W.; Womack, T.; Bricogne, G. Data processing and analysis with the autoPROC toolbox. Acta Crystallogr. Sect. D 2011, 67, $293-302$. [CrossRef] [PubMed]

34. Emsley, P.; Cowtan, K. Coot: Model-building tools for molecular graphics. Acta Crystallogr. D Biol. Crystallogr. 2004, 60, 2126-2132. [CrossRef] [PubMed]

Sample Availability: Samples of the compounds 32a-f are not available from the authors.

Publisher's Note: MDPI stays neutral with regard to jurisdictional claims in published maps and institutional affiliations.

(C) 2020 by the authors. Licensee MDPI, Basel, Switzerland. This article is an open access article distributed under the terms and conditions of the Creative Commons Attribution (CC BY) license (http://creativecommons.org/licenses/by/4.0/). 